Keywords: DWPF, glass, IDMS, durability, Product Consistency Test, vitrification, process control

WSRC-RP-91-371

WSRC-RP-91-371

DE93 002154

\title{
DURABILITY OF GLASSES FROM THE HG-DOPED INTEGRATED DWPF MELTER SYSTEM (IDMS) CAMPAIGN (U)
}

\section{CAROL M. JANTZEN}

Approved by

E.W. Holtzscheiter, Research Manager

Defense Waste Processing Technology

Publication Date: August 30, 1992

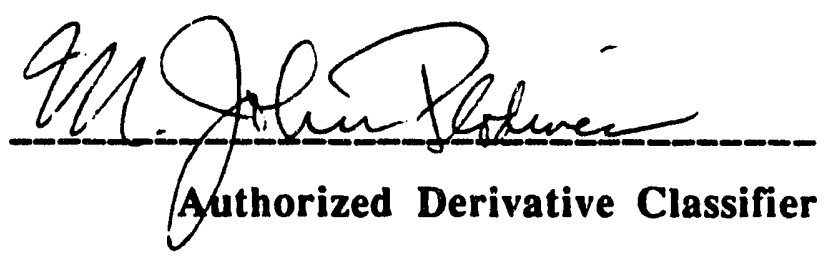

Westinghouse Savannah River Co. Savannah River Site

Aiken, SC 29808

PREPARED IOR THE U.S. DEPARTMENT OF ENERGY UNDER CONTRACT DE-AC09-89SR18035

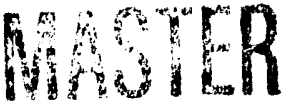


This page intentionally left blank.

$-2=$ 


\section{ABSTRACT}

The Integrated DWPF Melter System (IDMS) is designed and constructed to be a 1/9th scale prototype of the full scale Defense Waste Processing Facility (DWPF) melter. The IDMS facility is the first engineering scale melter system capable of processing mercury, and flowsheet levels of halides and noble metals. In order to determine the effects of mercury on the feed preparation process, the off-gas chemistry, glass melting behavior, and glass durability, a three-run mercury $(\mathrm{Hg})$ campaign was conducted. The glasses produced during the $\mathrm{Hg}$ campaign were composed of Batch 1 sludge, simulated precipitate hydrolysis aqueous product (PHA) from the Precipitate Hydrolysis Experimental Facility (PHEF), and Frit 202. The glasses were produced using the DWPF process/product models for glass durability, viscosity, and liquidus. The durability model indicated that the glasses would all be more durable than the glass qualified in the DWPF Environmental Assessment (EA). The glass quality was verified by performing the Product Consistency Test (PCT) which was designed for glass durability testing in the DWPF.

The durability of three glasses from each of the three runs was examined with the PCT. There was very little variation in the glass durability during run $\mathrm{HG}-1$ until excess $\mathrm{NaOH}$ was added to adjust the glass viscosity to be in the correct processing range. The addition of the excess $\mathrm{NaOH}$ caused the glasses in runs HG- 2 and HG-3 to be less durable than the glasses in run HG-1. The nine IDMS Hg glasses were of comparable durability to previously examined sludge-only 165 glasses and to glasses fabricated from Frit 202 with excess alkali. All the IDMS Hg glasses were over 20 times more durable than the glass that was qualified in the DWPF Environmental

Assessment (EA). The IDMS Hg campaign glasses would, therefore, meet current Wast: Acceptance Preliminary Specification (WAPS) criteria for product consistency. 
This page intentionally left blank. 


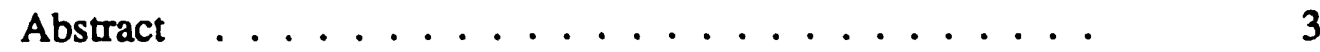

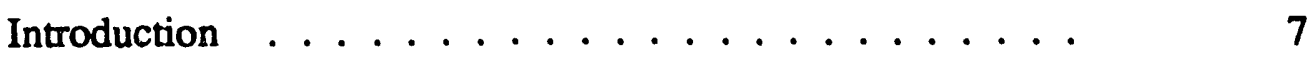

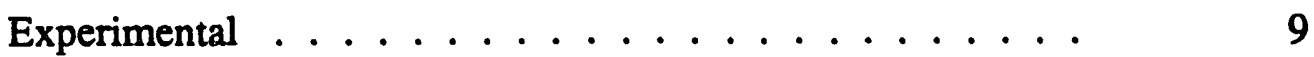

Glass Homogeneity . . . . . . . . . . . 9

Glass Composition . . . . . . . . . . . . 9

Glass Durability . . . . . . . . . . . . . 9

Quality Assurance.................. 10

Glass Sample Identification . . . . . . . . . . . . . 10

Results and Discussion ................ 11

Glass Homogeneity . . . . . . . . . . . . 11

Glass Composition ................ . . . 11

Glass Durability . . . . . . . . . . . . 13

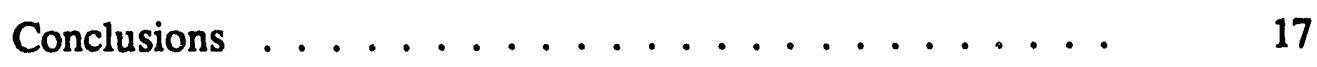

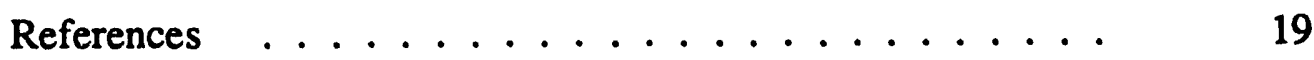

Appendix I : Measured Glass Compositions .......... 21

Appendix II: Leachate Multielement Standard Analyses . . . . 39

Appendix III: Leachate Daia for the IDMS Hg Campaigns 1, 2, 3 
This page intentionally left blank. 


\section{DURABILITY OF GLASSES FROM THE HG-DOPED INTEGRATED DWPF MELTER SYSTEM (IDMS) CAMPAIGN (U)}

\section{INTRODUCTION}

Liquid high-level nuclear waste will be immobilized at the Savannah River Site (SRS) by vitrification into borosilicate glass. The production process to be used in the Defense Waste Processing Facility (DWPF) is designed to reliably produce durable borosilicate nuclear waste glasses.

The Integrated DWPF Melter System (IDMS) was designed and constructed to be a $1 / 9$ th scale prototypic pilot plant of the full scale DWPF melter. The IDMS facility is the first engineering scale melter system operated at SRS that is capable of processing mercury, and flowsheet levels of halides and noble metals. The mercury, present in the waste due to the use of mercuric nitrate as a catalyst during nitric acid dissolution of spent fuel rods, decomposes at temperatures much less than the borosilicate glass melt temperature. Any mercury present in the waste at the time of vitrifir ation will likely exit the melter in the off-gas. Therefore, the DWPF has planned to remove most of the mercury prior to vitrification by reduction and steam stripping. ${ }^{1}$

In order to determine the effects of mercury on the feed preparation process, the off-gas chemistry, glass melting behavior, and glass durability, a mercury $(\mathrm{Hg})$ campaign was conducted in the IDMS. The IDMS was operated batch-style for three SRAT/SME (Slurry Receipt Adjustment Tank/Slurry Mix Evaporator) cycles. The facility was operated close to DWPF flowsheet conditions. The process/product models ${ }^{2}$ developed for DWPF were used in spreadsheet format since the DWPF process control system, the Product Composition Control System (PCCS) ${ }^{3}$ had not yet been fully implemented. Mercury containing Batch 1 sludge ${ }^{4}$ without noble metals was blended with precipitate hydrolysis aqueous (PHA) product and Frit 202. This PHA glass was designed to have similar process and product characteristics to SRS sludge-only glasses which were formulated without PHA. 5

A durability test, designated the Product Consistency Test (PCT), has been developed to measure the consistency of the glass product produced in the Defense Waste Processing Facility (DWPF) during routine production. ${ }^{6-8}$ The test was designed to meet the requirements of the Waste Acceptance Preliminary Specifications (WAPS) 1.3.9 Currently this specification states that based on comparative PCT analyses, a DWPF glass must have a release which is better than the glass that was qualified in the DWPF Environmental Assessment (EA). ${ }^{10}$ The PCT measurement of glass durability will take a minimum of 7 days. ${ }^{6-8}$ Therefore, a product quality model based on hydration free energy was developed. $11-17$ The use of the hydration thermodynamic model allows the glass quality to be predicted from the composition of vitrified melter feed, and then verified after production. 
This study documents the final glass chemistry and the measured glass durability of glasses produced during the IDMS-Hg campaign. Over 15,000 pounds of glass was poured during the entire campaign. This represented about 5000 pounds of glass for each of the three runs $(\mathrm{Hg}-1$, $\mathrm{Hg}-2$ and $\mathrm{Hg}-3$ ). Three samples of IDMS glass were taken from the beginning of each of the three runs $(\mathrm{Hg} \mathrm{1-1,} \mathrm{Hg} \mathrm{2-1,} \mathrm{Hg} \mathrm{3-1)}$, at the middle of each run $(\mathrm{Hg} \mathrm{1-2,} \mathrm{Hg} \mathrm{2-2}$ and $\mathrm{Hg} \mathrm{3-2})$, and at the end of each run ( $\mathrm{Hg} \mathrm{1-3,} \mathrm{Hg} \mathrm{2-3,} \mathrm{Hg} \mathrm{3-3).} \mathrm{This} \mathrm{represented} \mathrm{glass} \mathrm{pouring} \mathrm{intervals} \mathrm{of} \sim 0,2500$, and 5000 pounds of glass. The process/product properties calculated from the vitrified slurry are compared to the properties calculated from the final glass product as a function of run sequence. The measured glass durability is reported and compared to the following:

- the predicted glass durability

- previously tested SRS sludge-only and PHA glasses

- the sludge-only glass qualified in the DWPF Environmental Assessment. 


\section{EXPERIMENTAL}

\section{Glass Homogeneity}

X-ray Diffraction (XRD) and Scanning Electron Microscopy (SEM) analyses coupled with Energy Dispersive Analysis by X-ray (EDAX) were performed on the nine IDMS-Hg campaign glasses in order to determine the crystallinity and/or homogeneity of the glass.

\section{Glass Composition}

The elemental composition of the nine glasses was originally measured by the TNX laboratory. The glasses were reanalyzed by the Analytic Development Section of the Savannah River Technology Center because the original analyses were inconsistent. The nine glasses were analyzed for whole element chemistry and redox. The glass samples were analyzed by the following techniques:

- Dissolution by $\mathrm{Na}_{2} \mathrm{O}_{2}$ with an $\mathrm{HCl}$ uptake - ICP for Al, Ca, Fe, Mg, Mn, Li, Si, Cr, B, Sr, Ti, P, Ba, Pb, Mo, Zn, Cu, Ni, $\mathrm{La}, \mathrm{Cd}$

- Dissolution by $\mathrm{HCl} / \mathrm{HF}$ microwave

- ICP for $\mathrm{Na}, \mathrm{Zr}$

- AA for $\mathrm{Na}, \mathrm{K}$

- Dissolution by $\mathrm{H}_{2} \mathrm{SO}_{4} / \mathrm{HF}$ in the presence of $\mathrm{NH}_{4} \mathrm{VO}_{3}{ }^{18}$

- Colorimetric for $\mathrm{Fe}^{2+}$ and $\mathrm{Fe}$ (Total)

where ICP is Inductively Coupled Plasma Spectroscopy and AA is Atomic Absorption analysis.

\section{Glass Durability}

The durability of the nine glasses was studied using Version 3.0 of the PCT. ${ }^{8}$ In the PCT, crushed glass of 100-200 mesh is immersed in ASTM Type I water for 7 days at $90^{\circ} \mathrm{C}$. The volume of solution $(V)$ used was the recommended $10 \mathrm{~mL}$ per gram of glass. Leachates were filtered to remove colloids and/or particulates. At the end of triplicate analyses, both the $\mathrm{pH}$ and the leachate concentrations were measured for the glass species of interest. A standard glass was used as a control to eliminate bias in the experimental analysis and in the analytical data. Triplicate analyses and triplicate glass standards were run simultaneously. A multielement solution standard was used to detect any significant biases in the analysis of the leachates.

The leachate concentrations are reported as normalized elemental losses, $\mathrm{NC}_{\mathrm{i}}$, released from the glass in grams of glass per $\mathrm{L}$ of leachant. This has the advantage that the release concentrations in parts per million are normalized by the weight fraction of that element present in the glass. The 
normalized release, $\mathrm{NC}_{\mathrm{i}}$, is calculated as:

$$
\mathrm{NC}_{\mathrm{i}}=\frac{\mathrm{C}_{\mathrm{i}}}{\mathrm{F}_{\mathrm{i}}}
$$

where $\quad \mathrm{NC}_{\mathrm{i}}=$ normalized release $\left(\mathrm{g}_{\text {glass }} / \mathrm{L}_{\text {leachant }}\right)$

$\mathrm{C}_{\mathrm{i}}=$ mass of element $" \mathrm{i}$ " in the solution $\left(\mathrm{g}_{\mathrm{j}} / \mathrm{m}^{3}\right)$

$F_{i}=$ fraction of element " $i$ " in the glass $\left(g_{i} / g_{\text {glass }}\right.$ )

\section{OUALITY ASSURANCE}

All the vitrification activities and glass analyses were performed in accordance with DWPT Task Plan-IDMS Mercury Studies, DWPTQA-89-0041. All tasks were controlled in accordance with the task QA Plan.

The PCT Version 3.0 is a Glass Technology Category 1 Procedure requiring experimenter data input and signoff at every step (GTOP-3-025 in The Glass Technology Procedures Manual, DPSTM-88-700-5, L 13-1). All the ovens, balances, and water purification systems used for the PCT are M\&TE Category 1.

Analytical Development Section (ADS) procedures were followed for all chemical and x-ray diffraction data so that the data is readily retrievable.

All the PCT data for this study are recorded in DPSTN-4789 (E-56079) and WSRC-NB-90-271. The glass composition data is recorded in DPSTN-4771 (E-56053).

\section{GLASS SAMPLE IDENTIFICATION}

The glass nomenclature $\mathrm{Hg} 1-1,1-2,1-3$ was used to facilitate the understanding of the chemical variation occurring in the first ( $\mathrm{Hg}-1$ ) run of the IDMS $\mathrm{Hg}$ campaign as a function of the sequence in which the glasses were sampled. 19 Glasses $\mathrm{Hg} \mathrm{1-1,1-2,} \mathrm{and} \mathrm{1-3} \mathrm{appear} \mathrm{in} \mathrm{the} \mathrm{IDMS}$ production records as GLAS 2340, 2427, and 2518, respectively. Glasses $\mathrm{Hg} \mathrm{2-1,} \mathrm{2-2,} \mathrm{and} \mathrm{2-3}$ are GLAS 2630, 2838, and 2877, respectively. Glass $\mathrm{Hg} \mathrm{3-1}$ is a combined sample of production run GLAS 2124 and 2125. Glass $\mathrm{Hg}$ 3-2 is a combined sample of production run GLAS 3236 and 3237. Glass $\mathrm{Hg} \mathrm{3-3}$ is production run GLAS 3357. 


\section{RESULTS AND DISCUSSION}

\section{Glass Homogeneity}

The $\mathrm{x}$-ray diffraction analysis of the crushed and sieved glass indicated that there was no crystallization present in any of the IDMS-Hg glasses. During SEM/EDAX analysis of the crushed glass, small amounts of metallic $\mathrm{Cu}^{\circ}$ were observed. The $\mathrm{Cu}^{\circ}$ appeared to be on the glass surface, indicating that it may have been contamination from the brass sieves. No evidence of glass crystallization was observed during SEM/EDAX analysis.

\section{Glass Composition}

The chemical analyses indicated that there had been an excursion in $\mathrm{Na}_{2} \mathrm{O}$ content in the glass vitrified in IDMS between runs $\mathrm{Hg}-1$ and $\mathrm{Hg}-2$. This excursion occurred when the vitrified slurry analyses indicated that the resulting melt would be too viscous to pour, e.g., over the viscosity process control limit of 100 poise. ${ }^{19} \mathrm{NaOH}$ was added to run $\mathrm{Hg}-2$ to adjust the feed so that it would form a glass of $<100$ poise viscosity. Additional $\mathrm{PHA}$, which is $\mathrm{Na}_{2} \mathrm{O}$ rich, was added to the run $\mathrm{Hg}-3$ feed instead of $\mathrm{NaOH}$, so that the $\mathrm{Hg}-3$ run glass would conform to the viscosity process limit of $<100$ poise.

Analysis of the glass used in the durability studies indicated that the glasses run during run $\mathrm{Hg}-1$ ( $\mathrm{Hg} \mathrm{1-1,} \mathrm{Hg} \mathrm{1-2,} \mathrm{and} \mathrm{Hg} \mathrm{1-3)}$ and the very first sample taken at the beginning of run $\mathrm{Hg}-2$ ( $\mathrm{Hg} \mathrm{2-}$ 1) were consistent in composition while the sequence of glasses after the $\mathrm{NaOH}(\mathrm{Hg} \mathrm{2-2,} \mathrm{Hg} \mathrm{2-3})$ and the PHA ( $\mathrm{Hg} \mathrm{3-1,} \mathrm{Hg} \mathrm{3-2,} \mathrm{Hg} \mathrm{3-3)} \mathrm{additions} \mathrm{were} \mathrm{consistent.} \mathrm{The} \mathrm{glass} \mathrm{compositions} \mathrm{were}$ measured in duplicate and were determined to be biased low compared to the original analyses of these glasses at the TNX laboratory. Therefore, the reanalyzed glass compositions were biascorrected to the original IDMS Hg-1 glass data (Appendix I). The measured redox ratios $\left(\mathrm{Fe}^{2+} \sqrt{\Sigma \mathrm{Fe}}\right)$ of the IDMS glasses were $<0.05$ during runs $\mathrm{Hg}-1$ and $\mathrm{Hg}-2$ and between 0.07 and 0.1 during run $\mathrm{Hg}-3$ (Appendix I). The measured redox for $\mathrm{Hg}-1$ and $\mathrm{Hg}-2$ glasses were more oxidizing than those measured from the vitrified feed for $\mathrm{Hg}-1$ and $\mathrm{Hg}-2$. The measured redox for $\mathrm{Hg}-3$ glasses was slightly more reduced than the redox measured from the vitrified feed for $\mathrm{Hg}-3.19$

The effect of the glass composition variability calculated for each of the compositionally dependent process (viscosity and liquidus) and product (durability) constraints is shown in Figure la-c as a function of production run sequence. The process and product parameters calculated from the average gliss compositions given in Appendix I followed the same trends as the parameters calculated ${ }^{19}$ from the vitrified melter feed for all runs. The chemical analysis of vitrified feed from run $\mathrm{Hg} \mathrm{2-1}$ indicated that the melt would have exceeded the upper viscosity limit of 100 poise (Figure 1a) and the upper liquidus temperature of $10500^{\circ} \mathrm{C}$ (Figure $1 \mathrm{~b}$ ) had the glass composition not been remediated to the value indicated by the $\mathrm{Hg} \mathrm{2-2}$ glass analysis. Glass $\mathrm{Hg} \mathrm{2-1}$ had been sampled early in run 2 before the melt volume had completely turned over after the addition of the $\mathrm{NaOH}$. Moreover, Figure $1 \mathrm{c}$ indicates that the remediation of the glass composition within the process constraints did not adversely affect the glass durability, e.g. the calculated glass durability, expressed as the glass free energy of hydration, remained a more positive value than $-7 \mathrm{kcal} / \mathrm{mole}$. 


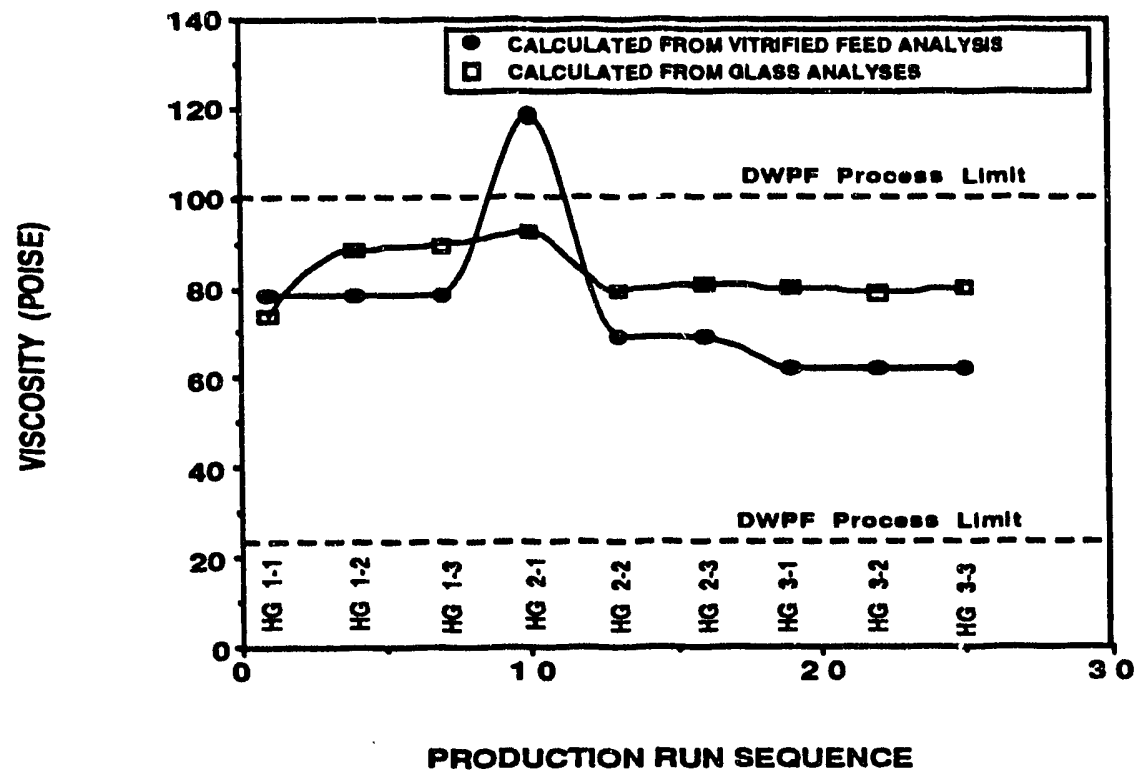

Figure 1a. Comparison of predicted glass viscosity based on vitrified feed analyses and final glass composition analysis.

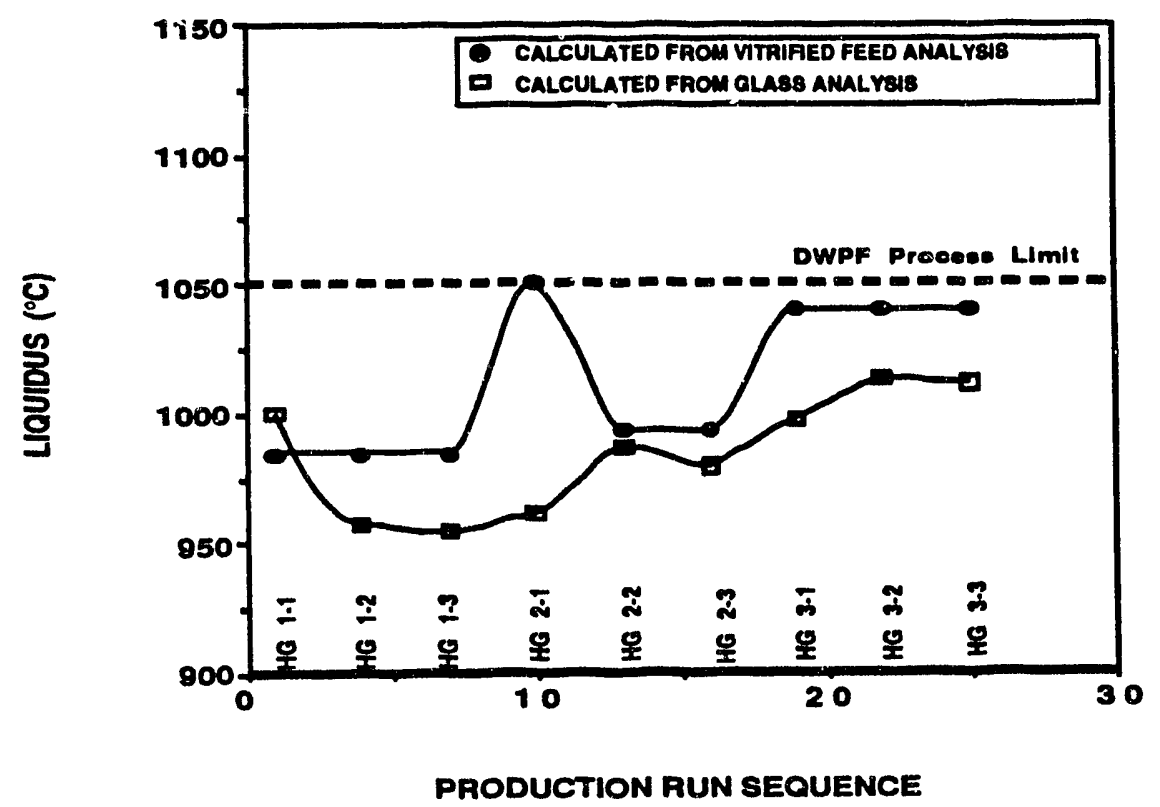

Figure 1b. Comparison of predicted glass liquidus based on vitrified feed analyses and final glass product analysis. 


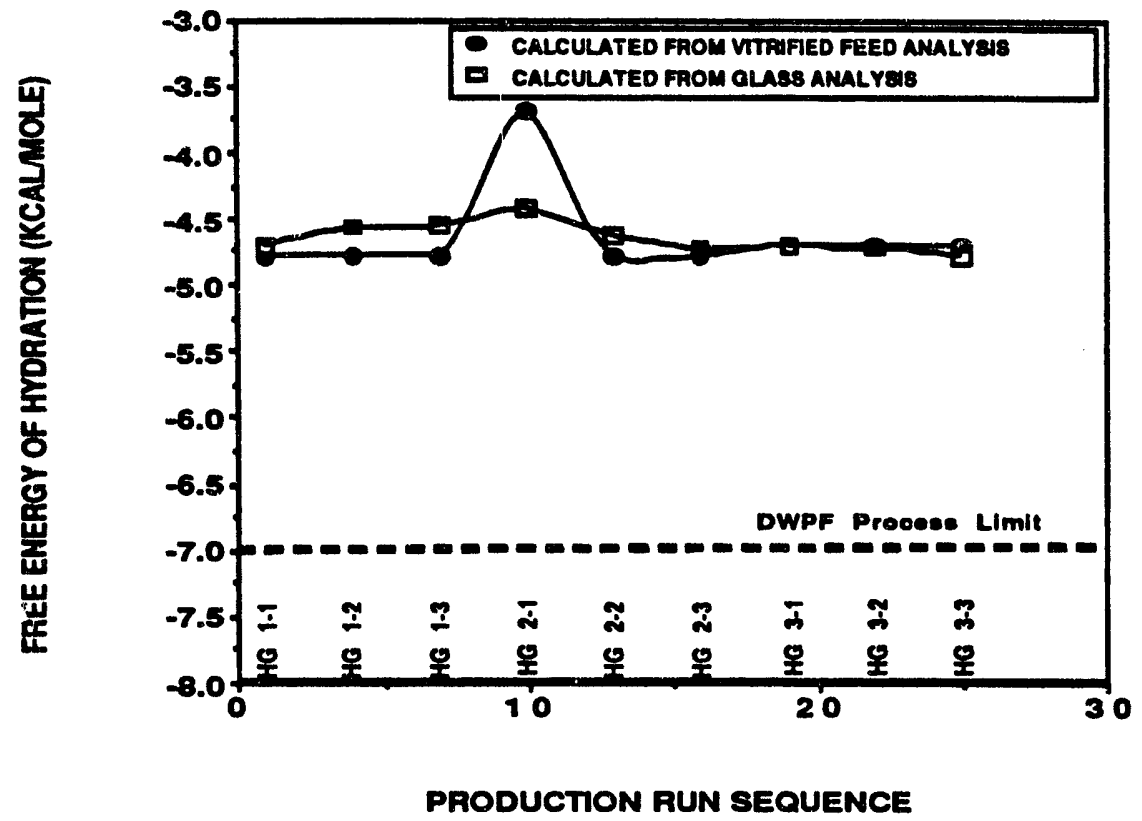

Figure 1c. Comparison of predicted glass liquidus based on vitrified feed analyses and final glass product analysis.

\section{Glass_Durability}

The triplicate glass durability analysis $\mathrm{pH}$ values shown in Figure 2 also reflect the changing alkali content of the Hg campaign glass as a function of production run sequence. The leachate $\mathrm{pH}$ changed significantly between campaign $\mathrm{Hg} \mathrm{2-1}$ and $\mathrm{Hg}$ 2-2 when the excess $\mathrm{NaOH}$ addition to the sludge became a significant contribution in the resulting glass. This is not surprising since excess $\mathrm{Na}_{2} \mathrm{O}$ in the glass would cause excess $\mathrm{OH}^{-}$in the leachate which causes the leachate $\mathrm{pH}$ to become more basic via the following reaction:

$$
\mathrm{Na}_{2} \mathrm{SiO}_{3}+2 \mathrm{H}_{2} \mathrm{O} \rightarrow 2 \mathrm{Na}^{+}+\mathrm{H}_{2} \mathrm{SiO}_{3}+2 \mathrm{OH}^{-}
$$

The $\mathrm{pH}$ corrected free energy of hydration was calculated from the glass composition and the leachate $\mathrm{pH}$ (Appendix I). ${ }^{12}$ The $\mathrm{pH}$ corrected free energy of hydration was plotted as a function of glass production run sequence for the IDMS-Hg glasses (Figure 3). A significant change in the free energy of hydration, $\Delta G_{\text {hyd }}$, is noted between runs $\mathrm{Hg} \mathrm{2-1}$ where the calculated value is about $-7 \mathrm{kcal} / \mathrm{mole}$ and $\mathrm{Hg} 2-2$ where the calculated value is about $-8 \mathrm{kcal} / \mathrm{mole}$. The change in the $\mathrm{pH}$ corrected $\Delta \mathrm{G}_{\text {hyd }}$ coincided with the the point at which the excess $\mathrm{Na}_{2} \mathrm{O}$ became a significant contribution to the glass. 


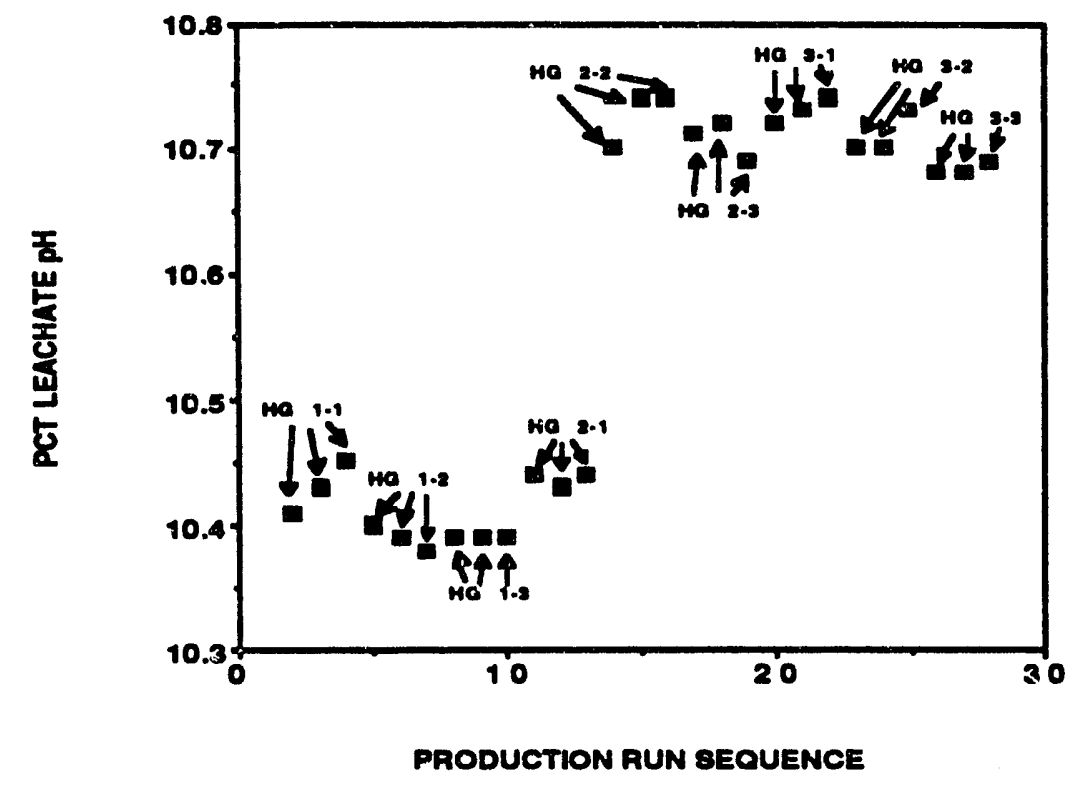

Figure 2. Variation of leachate $\mathrm{pH}$ with $\mathrm{DDMS} \mathrm{Hg}$ glasses in the $s$.quence in which the glasses were produced and poured.

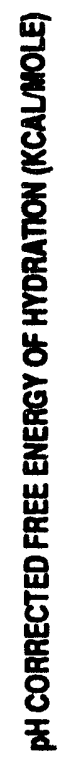

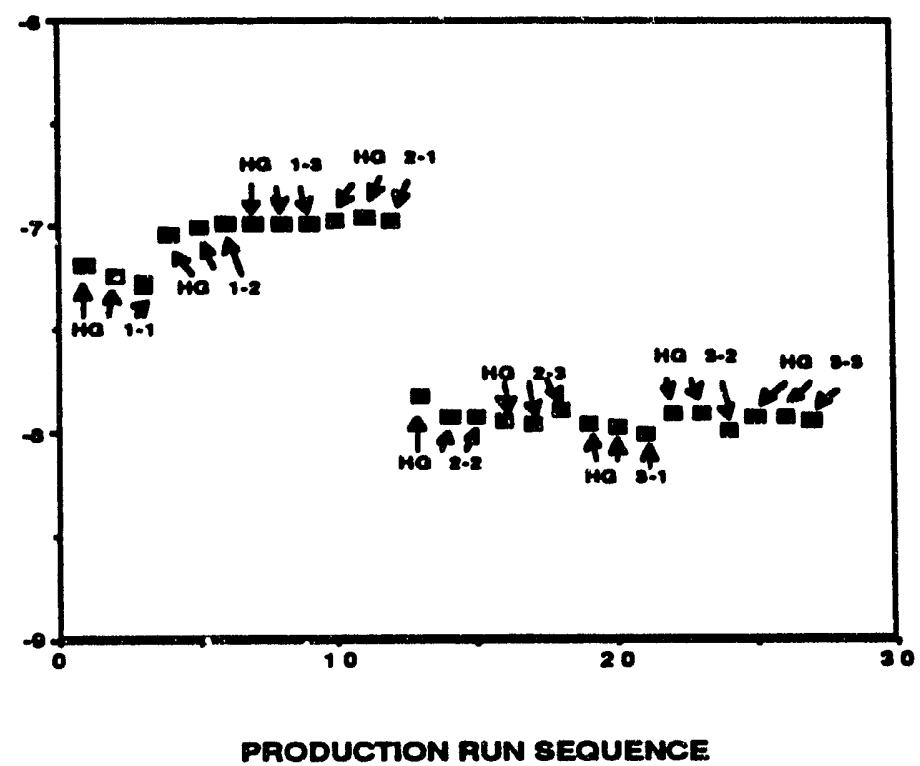

Figure 3. Variation of the calculated free energy of hydration (calculated from the glass composition and the solution $\mathrm{pH}$ ) for IDMS $\mathrm{Hg}$ glasses shown in the sequence in which the glasses were produced and poured. 
A multielement solution standard was run after every 5 leachate samples. Analysis of the solution standard data indicated that there was less than $0.5 \mathrm{ppm}$ bias in the ICP analyses for $\mathrm{Na}, \mathrm{B}, \mathrm{Li}, \mathrm{Al}$, and $\mathrm{Fe}$ and in the Atomic Absorption (AA) analyses for $\mathrm{K}$. The data also indicated that there was about a $1.4 \mathrm{ppm}$ bias in the $\mathrm{Na}$ determinations made by $\mathrm{AA}$ and a -1.47 bias in the $\mathrm{Si}$ determinations by ICP analysis (Appendix II).

The raw data used to convert the leachate concentrations to $\mathrm{NC}_{\mathrm{i}}$ is given in Appendix III. Boron and lithium releases from glass are considered to be the most accurate indicators of glass duratility since these elements are leached from glass faster than any other elements. Boron is probably the best indicator of glass durability because it does not saturate in the leachate and does not participate in precipitation reactions caused by solution supersaturation. The elemental releases measured in the leachates were checked for internal consistency by plotting the normalizeci releases for $\mathrm{Li}, \mathrm{Si}$, $\mathrm{Na}$, and $\mathrm{K}$ against the normalized releases of $\mathrm{B}$ (Figure 4). Normalized units are plotted since the glasses before run $\mathrm{Hg} \mathrm{2-2}$ are considerably different in composition than those after run $\mathrm{Hg} \mathrm{2-2}$. The plots of $\mathrm{Li}, \mathrm{Si}, \mathrm{Na}$ and $\mathrm{K}$ versus $\mathrm{B}$ were all consistent, e.g. if a given glass released a great deal of $\mathrm{B}$ it, likewise, released a great deal of $\mathrm{Li}$ and/or $\mathrm{Si}, \mathrm{Na}$, or $\mathrm{K}$. Figure 4 also demonstrates a consistently high bias in the $\mathrm{Na}$ analyses by AA over the $\mathrm{Na}$ analyses by ICP.

The normalized elemental release of $B$ was plotted against the $\mathrm{pH}$ corrected $\Delta \mathrm{G}_{\text {hyd }}$. The elemental release of B from the IDMS Hg glasses were compared with PCT results from previous experimentation (Table 1 and Figure 5). The previous experimental results had been collected prior to May 1989. Historical controi charting of the ARM-1 standard glass indicated a shift in the elemental releases for all elements in May 1989. This shift correlated with a change from PCT 2.0 to PCT 3.0 when a glass powder washing procedure was introduced to remove adhering fine particles from the sieved glass. Since removal of the glass fines prior to conducting the durability test biases the PCT 3.0 leachate data lower than the historic data, the historic data was bias corrected to be consistent with the data derived from PCT 3.0.

The bias corrected normalized B release for the historic data and the PCT 3.0 leachate data for the $\mathrm{Hg}$ glasses was plotted against the $\Delta \mathrm{G}_{\text {hyd }}$ calculated from the glass composition and the solution $\mathrm{pH}$. This comparison indicated that the glasses from the IDMS $\mathrm{Hg}-1$ campaign $(\mathrm{Hg} \mathrm{1-1,} \mathrm{Hg} \mathrm{1-2}$ and $\mathrm{Hg} \mathrm{1-3)}$ and the glass frorn the first sample of the $\mathrm{Hg}-2$ campaign $(\mathrm{Hg} \mathrm{2-1})$ were very similar in durability to DWPF startup glass, 165 sludge-only glasses, and Frit 202 glass with excess alkali (Figure 5). The remaining glasses in the $\mathrm{Hg}-2$ campaign ( $\mathrm{Hg} \mathrm{2-2}$ and $\mathrm{Hg} \mathrm{2-3}$ ) and in the $\mathrm{Hg}-3$ campaign ( $\mathrm{Hg} \mathrm{3-1,} \mathrm{Hg} 3-2$, and $\mathrm{Hg} 3-3$ ) were higher in $\mathrm{Na}_{2} \mathrm{O}$ content due to $\mathrm{NaOH}$ addition during run $\mathrm{Hg}-2$ and the excess $\mathrm{PHA}$ addition during run $\mathrm{Hg}-3$ in order to adjust the glass viscosity. These glasses were less durable than the Frit 202 glass with excess PHA but more durable than 131 sludge-only glasses. All the IDMS $\mathrm{Hg}$ glasses are more durable than the glass that was qualified in the DWPF Environmental Assessment (EA). ${ }^{10}$ Comparisons of the data in Table 1 for the average EA glass leachate concentrations and the data in Appendix I for the $\mathrm{Hg}$ Campaign glasses indicates that the $\mathrm{Hg}$ Campaign glasses are over 20 times more durable than the EA glass. The IDMS Hg campaign glasses would, therefore, meet current Waste Acceptance Preliminary Specification (WAPS) criteria for product consistency. 

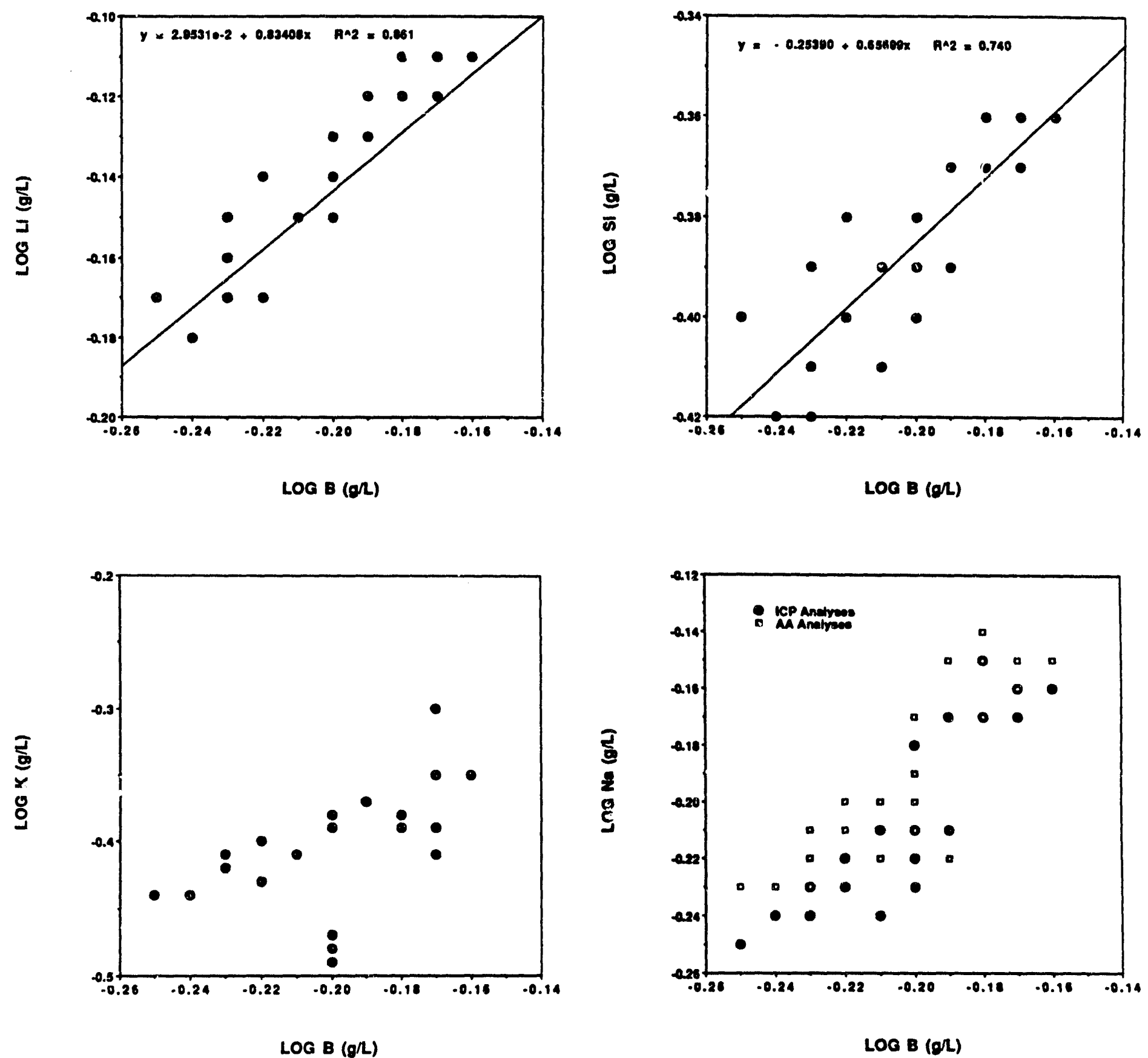

Figure 4. Internal consistency of IDMS leachate analyses. Note that the IDMS leachate analyses are significantly lower than the average values of $\mathrm{Li}, \mathrm{Na}, \mathrm{B}$ and $\mathrm{Si}$ for the EA glass which are $189 \pm 17,1650 \pm 131$, and $576 \pm 46,882 \pm 105 \mathrm{ppm}$, respectively. See Table 1 . 


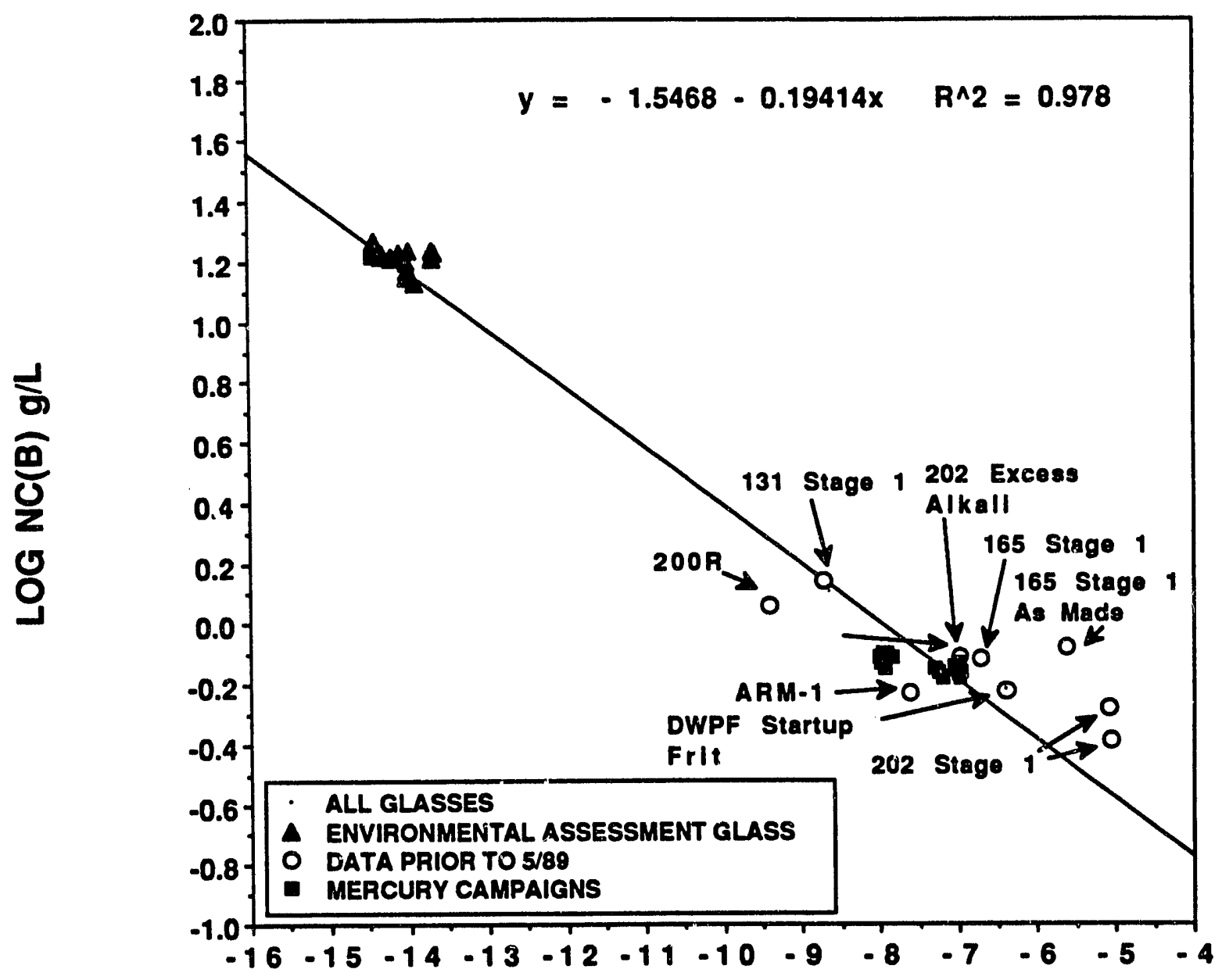

\section{pH CORRECTED FREE ENERGY OF HYDRATION (Kcal/mole)}

Figure 5. Correlation of the free energy of hydration, $\Delta G_{\text {hyd }}$, calculated from the glass composition and the leachate $\mathrm{pH}$, versus the logarithm of the normalized boron release from glasses investigated for the Defense Waste Processing Facility (DWPF). The measured durability values for the IDMS Hg-1, $\mathrm{Hg}-2$, and $\mathrm{Hg}-3$ campaigns with Batch 1 sludge, PHA, and 202 frit are overlain for reference.

\section{CONCLUSIONS}

Glasses produced during the three IDMS Hg run campaigns were produced using the DWPF process/product models. The durability model indicated that the glasses would all be more durable than the glass qualified in the DWPF Environmental Assessment (EA). The measured glass durability demonstrated that the $\mathrm{Hg}$ campaign glasses were as durable as previously examined Frit 202 PHA glasses and sludge-only 165 glasses and more durable than the EA glass. The IDMS Hg glasses, therefore, meet the current Waste Acceptance Preliminary Specification (WAPS) 1.3 criteria for control of product consistency. 
Table 1. Calculated Free Energies of Hydration and PCT Durability of DWPF Borosilicate Waste Glasses

\begin{tabular}{|c|c|c|c|c|c|c|c|}
\hline Glass/Reference & $\begin{array}{l}\text { pH Corrected } \\
\text { Free Energy } \\
\text { of Hydration } \\
\text { (Kcal/mole) }\end{array}$ & $\begin{array}{l}\log \\
\text { NC(Si) }\end{array}$ & $\begin{array}{c}\log \\
\mathrm{NC}(\mathrm{B}) \\
\quad(\mathrm{g})\end{array}$ & $\begin{array}{l}\log \\
\text { NC(Na) } \\
\text { s } L_{\text {leachat }}\end{array}$ & $e^{\mathrm{L}^{\log (\mathrm{Li}}}$ & $\mathrm{pH}$ & PCT \\
\hline $\begin{array}{l}\text { EA Glass-Average } \\
\text { of } 24 \text { PCT Tests } 20\end{array}$ & -14.05 & 0.58 & 1.21 & 1.12 & 0.98 & 11.92 & 3.0 \\
\hline $\begin{array}{l}202 \text { Stage } 1 \\
(\mathrm{AH}-10)\end{array}$ & -5.050 & $-0.53^{*}$ & $-0.39^{*}$ & $-0.51^{*}$ & -0.35 & 9.59 & 2.1 \\
\hline
\end{tabular}

DPSTN-4724

165 Stage 1

(AH-165)

DPSTN-4630

165 Standard

(Corning)

DPSTN-4575

DWPF Startup

Frit-Remelted

DPSTN-4630

202-Stage 1

Excess Alkali

(Corning 202P)

DPSTN-463C

200 Average

Radioactive

DPSTN-4570

131 Stage 1

(AH 131)

DPSTN-4630

202-Stage 1

(Corning 202G)

$-5.62$

$-6.72$

$-6.39$

$-0.90$

$-0.29^{*}$

$-0.12^{*}$

$-0.07^{*}$

$-0.14^{*} 10.31$

2.0

$-6.99$

$-0.41^{*}$

$-0.11^{*}$

$-0.08^{*}$

$-0.16^{*} 10.18$

2.1

$-0.33$

0.06

0.00

$\begin{array}{ll}-0.01 & 10.55\end{array}$

$-0.51$

0.14

0.10

$0.02 \quad 10.43$

$2.1 \mathrm{~W}$

DPSTN-4631

$2.1 \mathrm{~W}$

Solution data corrected for Si bias of $-13.31 \mathrm{ppm}, \mathrm{B}$ bias of $-4.10 \mathrm{ppm}, \mathrm{Na}$ bias of $-8.4 \mathrm{ppm}$, and an Li bias of -3.34 ppm; higher solution values were noted when glass fines were not removed from the meshed glass prior to durability testing (PCT 2.0 and 2.1). PCT 2.1W indicates PCT procedure 2.1 with fines washing and these data are directly comparable to data from PCT 3.0 without bias correction. 


\section{REFERENCES}

1. R. E. Eibling and J.R. Fowler, "Mercury Reduction and Removal During HighLevel Radioactive Waste Processing and Vitrification," Scientific Basis for Nuclear Waste Managment, IV, S.V. Topp (Ed.), Elsevier Publishers, New York, $61 \%-622(1982)$.

2. C.M Jantzen, "Relationship of Glass Composition to Glass Viscosity, Resistivity, Liquidus Temperature, and Durability: First Principles ProcessProduct Models for Vitrification of Nuclear Waste," Proceedings of the 5th International Symposium on Ceramics in Nuclear Waste Management, G.G. Wicks, D.F. Bickford, and R. Bunnell (Eds.), American Ceramic Society, Westerville, OH, 37-51 (1991).

3. K.G. Brown, R.L. Postles, and R.E. Edwards, "The Product Composition Control System (PCCS)," Proceedings of the 5th International Symposium on Ceramics in Nuclear Waste Management, G.G. Wicks, D.F. Bickford, and R. Bunnell (Eds.), American Ceramic Society, Westerville, OH, 37-51 559-568 (1991).

4. Waste Form Compliance Plan for the Defense Waste Processing Facility," USDOE Report WSRC-SW4-6, Rev. 0, Westinghouse Savannah River Co., Savannah River Laboratory, Aiken, SC (March, 1990).

5. C. M. Jantzen, "Glass Compositions and Frit Formulations Developed for DPWF," USDOE Report DPST-88-952, E.I. duPont deNemours \& Co., Savannah River Laboratory, Aiken, SC (November, 1988).

6. C. M. Jantzen and N. E. Bibler, "Product Consistency Test (PCT) and Test Protocol," USDOE Report DPST-87-575, E.I. duPont deNemours \& Co., Savannah River Laboratory, Aiken, SC (1987).

7. C.M. Jantzen and N.E. Bibler, "The Product Consistency Test for the DWPF Wasteform," Requirements for Waste Acceptance and Quality Control, Proceedings of the 2nd International Seminar on Radioactive Waste Products, E. Warnecke, R. Odoj, and R. Simon (Eds.), Kernforschunganlanger (KFA) Research Centre Julich, Federal Republic of Germany, 609-622 (1990).

8. C.M. Jantzen and N.E. Bibler, "Nuclear Waste Glass Product Consistency Test (PCT)-Version 3.0," USDOE Report WSRC-TR-90-539, Rev. 1, Westinghouse Savannah River Co., Aiken, SC (November, 1990).

9. Waste Acceptance Preliminary Specifications for the Defense Waste Processing Facility High-Level Waste Form, U. S. Department of Energy, Office of Civilian Radioactive Waste Management, USDOE Document OGR/B-8, Washington, DC (1988).

10. U.S. Department of Energy, "Environmental Assessment Waste Form Selection for SRP High-Level Waste," U.S. DOE Report DOE-EA-0179 (July, 1982). 
11. M.J. Plodinec, C.M. Jantzen, and G.G. Wicks, "Thermodynamic Approach to Prediction of the Stability of Proposed Radwaste Glasses," Advances in Ceramics. 8, 491-495 (1984).

12. C.M. Jantzen and M.J. Plodinec, "Thermodynamic Model of Natural, Medieval, and Nuclear Waste Glass Durability," L.Non-Cryst. Solids. 67, 207-233 (1984).

13. M.J. Plodinec, C.M. Jantzen, and G.G. Wicks, "Stability of Radioactive Waste Glasses Assessed from Hydration Thermodynamics," Sci. Basis for Nuclear Waste Management. VII G.L. McVay (ed). Elsevier Publ., New York 755-762 (1984).

14. C.M. Jantzen, "Prediction of Nuclear Waste Glass Durability from Natural Analogs" Advances in Ceramics, 20, D.E. Clark, W.B. White and A.J. Machiels (Eds.), American Ceramic Society, Westerville, OH, 703-712 (1986).

15. C.M. Jantzen, "Prediction of Glass Durability as a Function of Environmental Conditions", Proceedings of the Sympsoium on Materials Stability and Environmental Degredation," A. Barkatt et. al. (Eds.), Materials Research Society, Pittsburgh, PA, 143159 (1988).

16. C.M. Jantzen, "Prediction of Glass Durability as a Function of Glass Composition and Test Conditions: Thermodynamics and Kinetics", Broceedings of the First Intl. Conference on Advances in the Fusion of Glass. American Ceramic Society, Westerville, OH , p. 24.1-24.17 (1988).

17. C.M. Jantzen, "Thermodynamic Approach to Glass Corrosion," Corrosion of Glass. Ceramics, and Ceramic Superconductors, Noyes Publications, Park Ridge, NJ, 153-215 (1992).

18. E.W. Baumann, "Colorimetric Determination of Iron (II) and Iron (III) in Glass," Analyst. v. 117 913-916 (1992).

19. N.D. Hutson, J.R. Zamecnik, M.E. Smith, D.H. Miller and J.A. Ritter, "Integrated DWPF Melter System (IDMS) Campaign Report: Mercury Operation," USDOE Report WSRC-TR-91-0363, Westinghouse Savannah River Co., Savannah River Laboratory, Aiken, SC (May, 1991).

20. C.M. Jantzen, "Characterization of the Defense Waste Processing Facility (DWPF) Environmental Assessment (EA) Glass Standard Reference Material," USDOE Report WSRC-TR-92-346, Rev. 0, Westinghouse Savannah River Co., Savannah River Laboratory, Aiken, SC (September, 1992). 


\section{APPENDIX I Measured Glass Compositions}
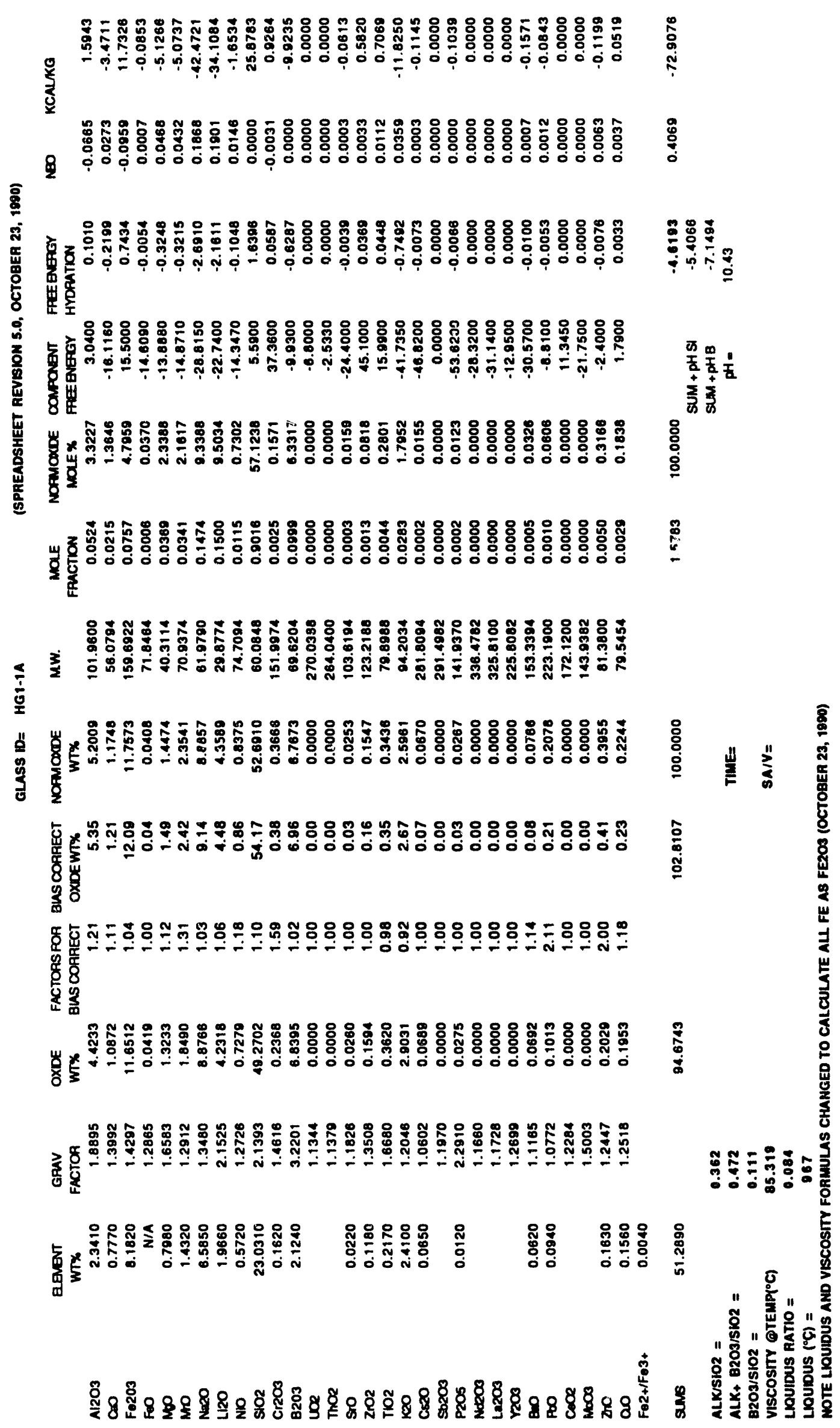


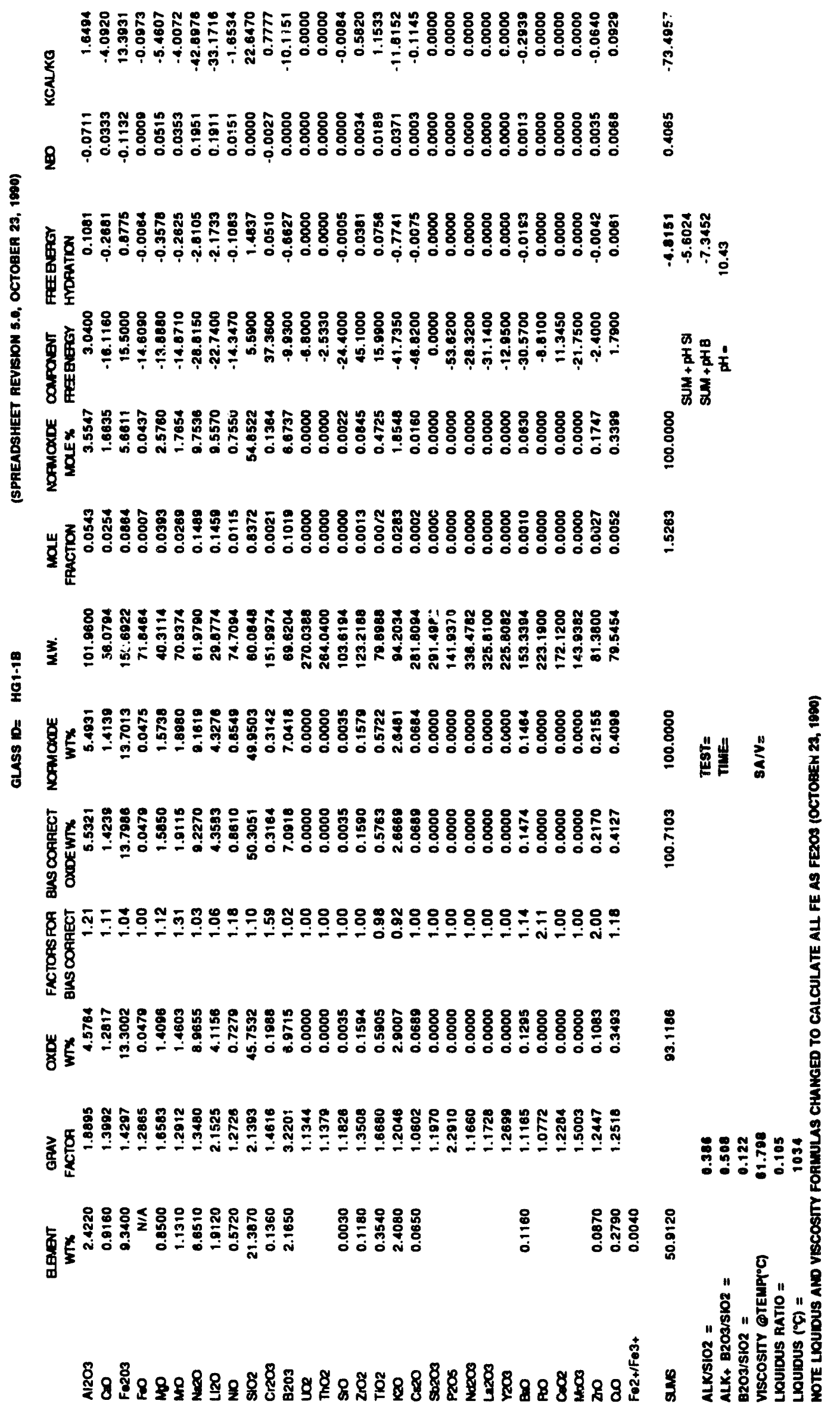




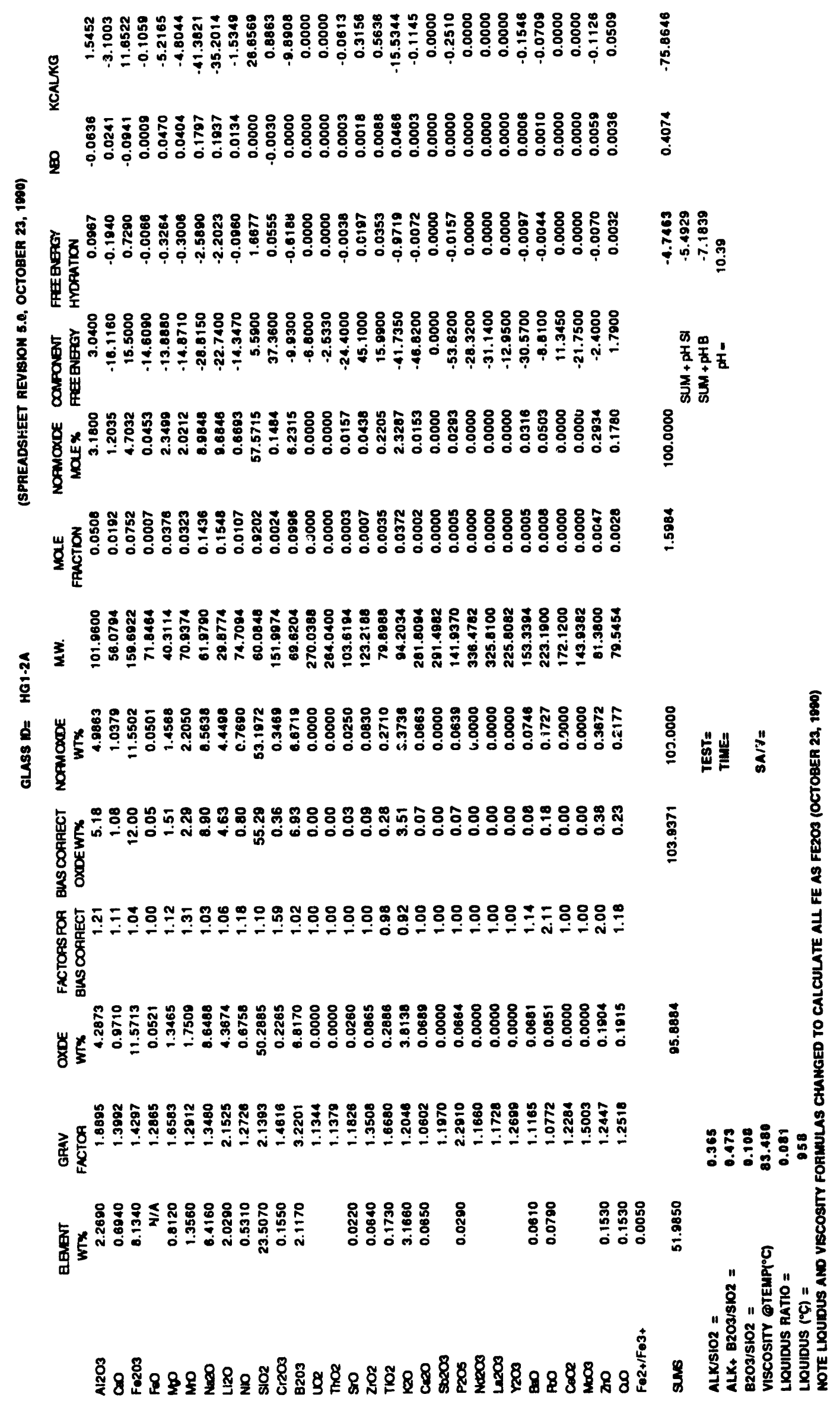




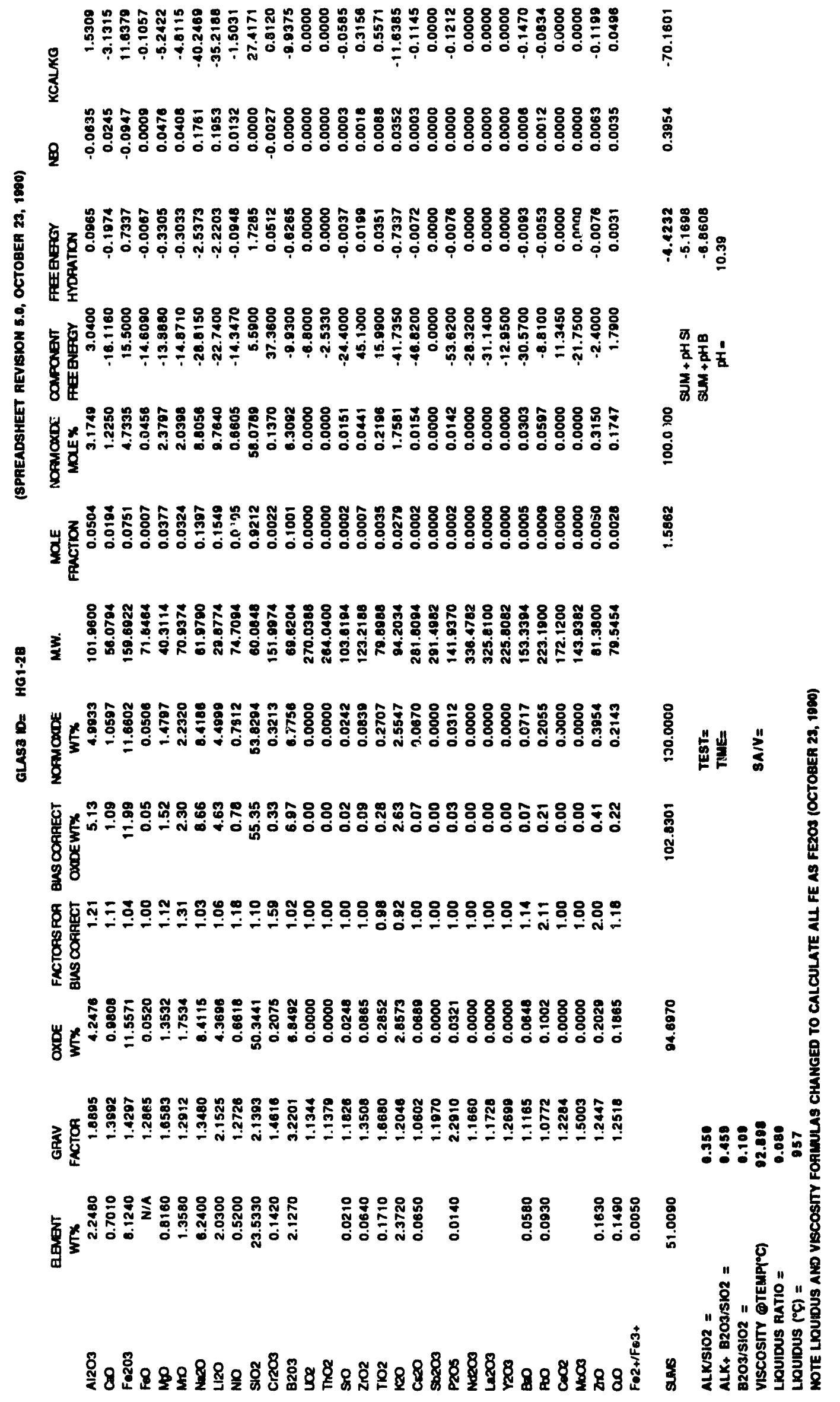




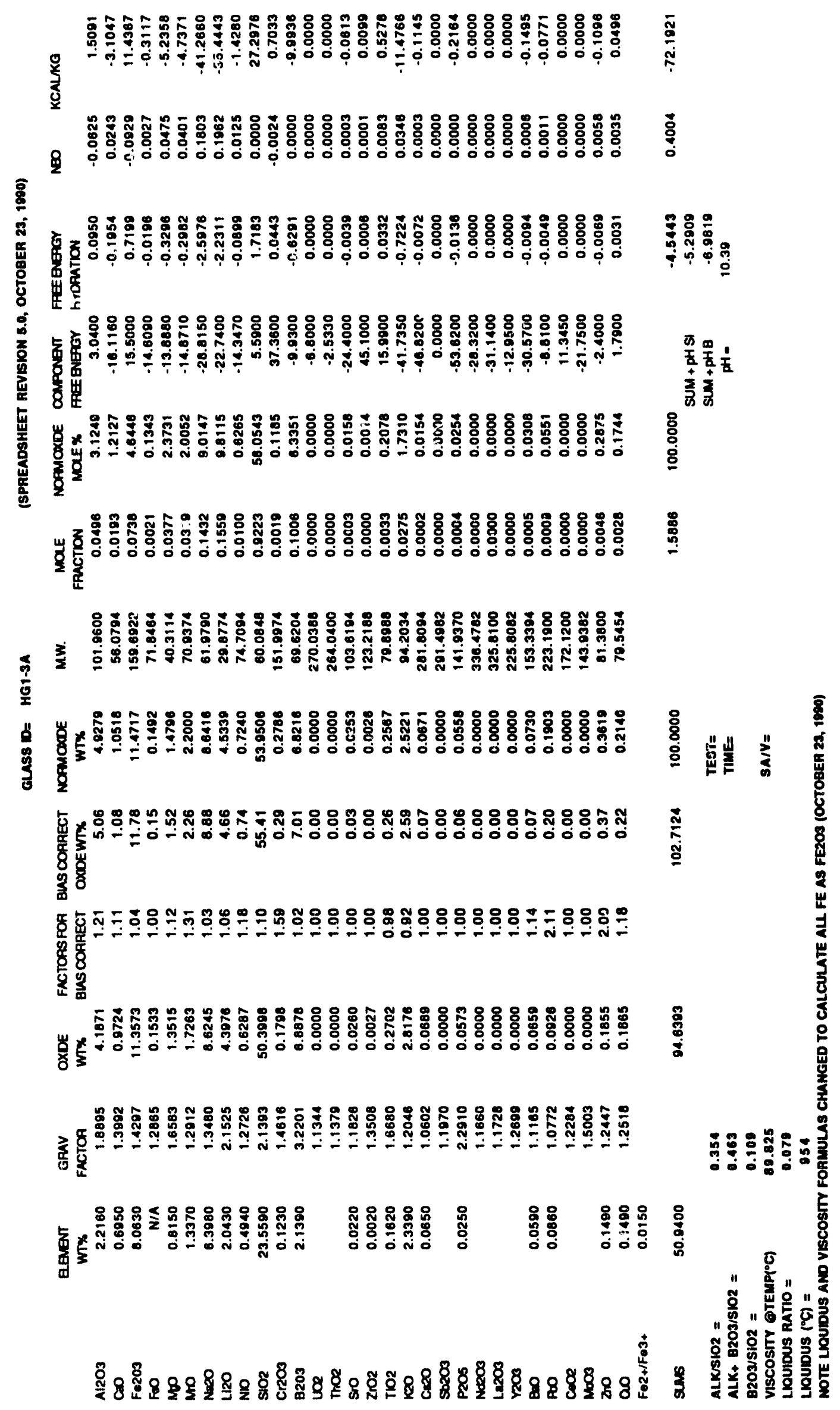




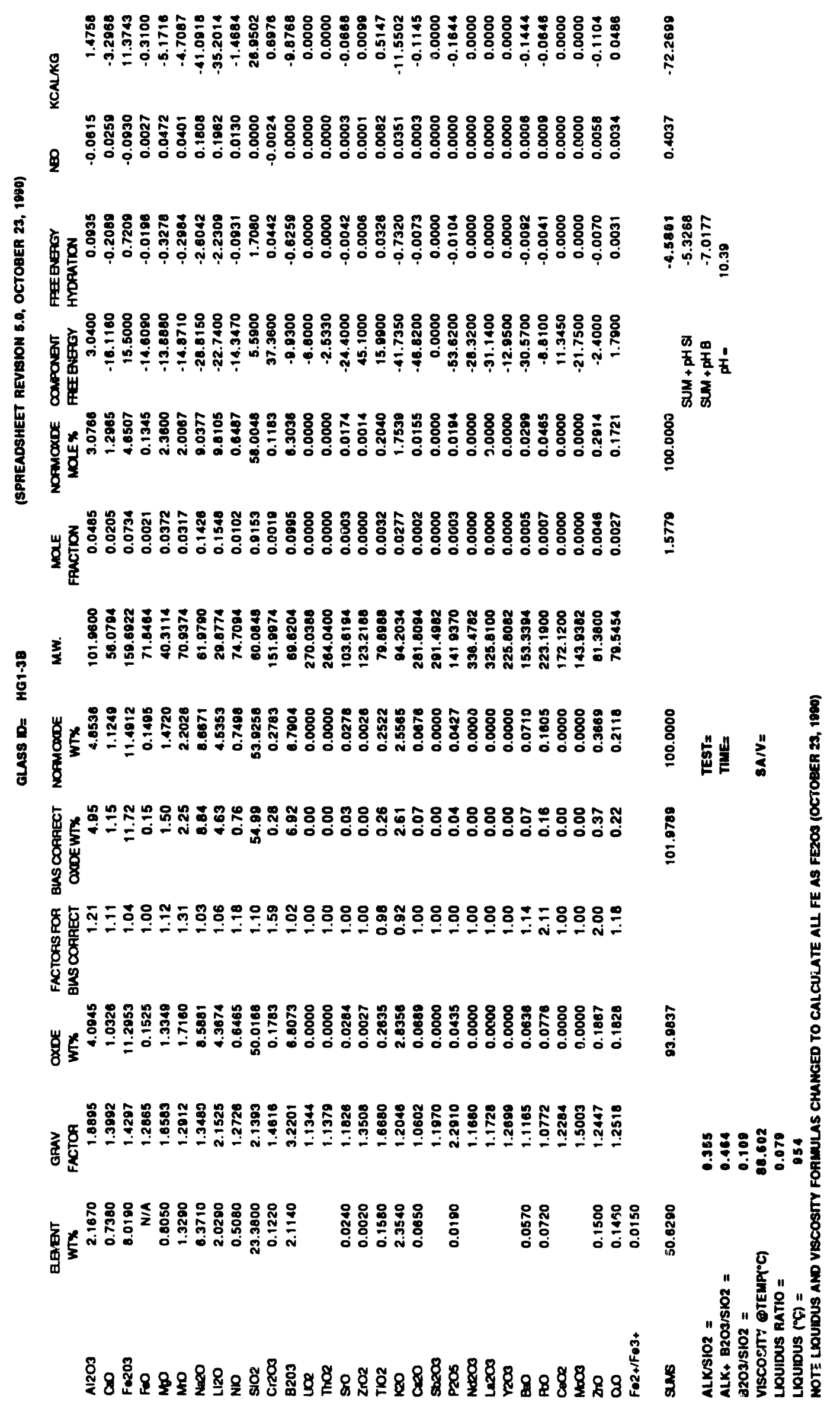




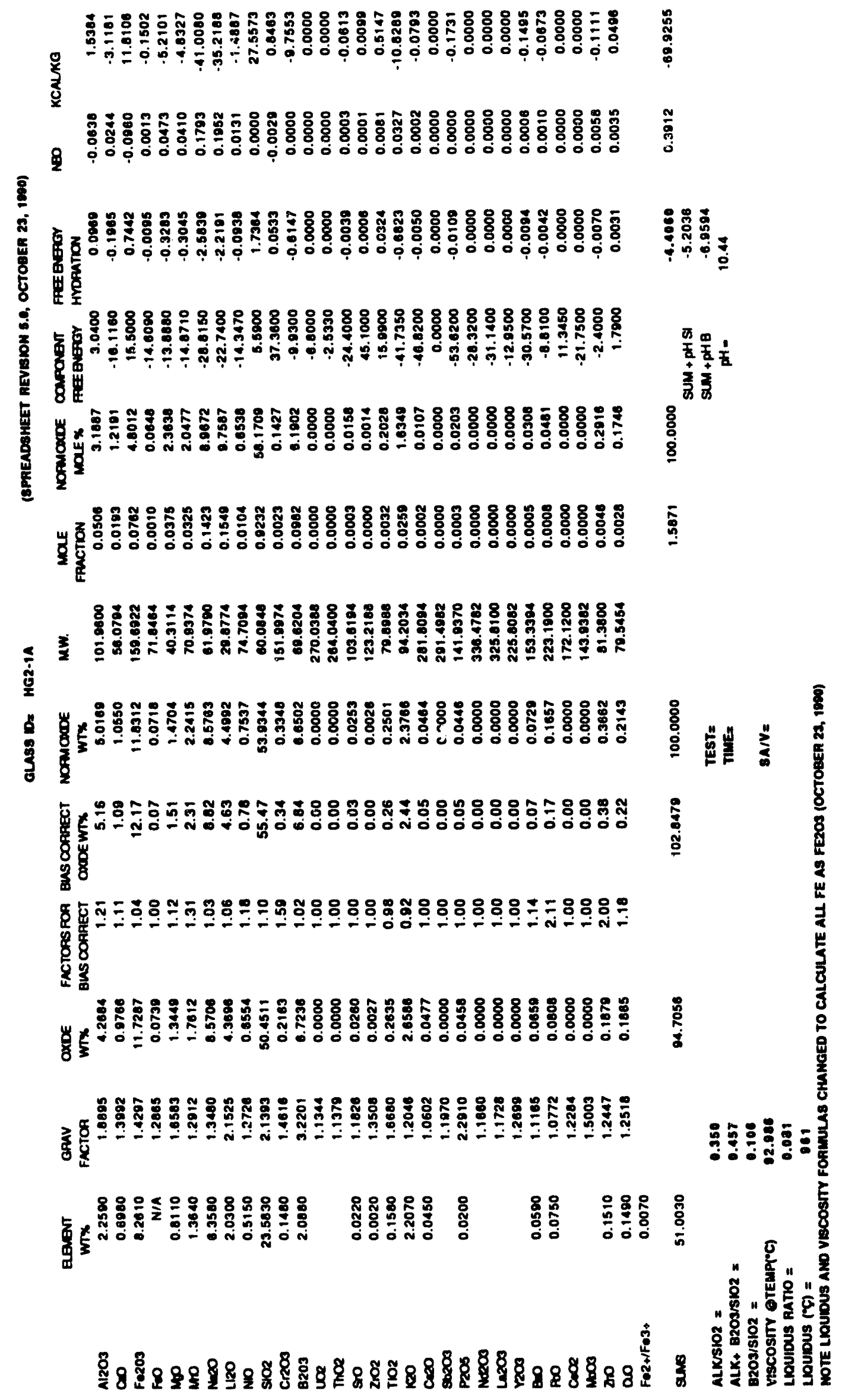




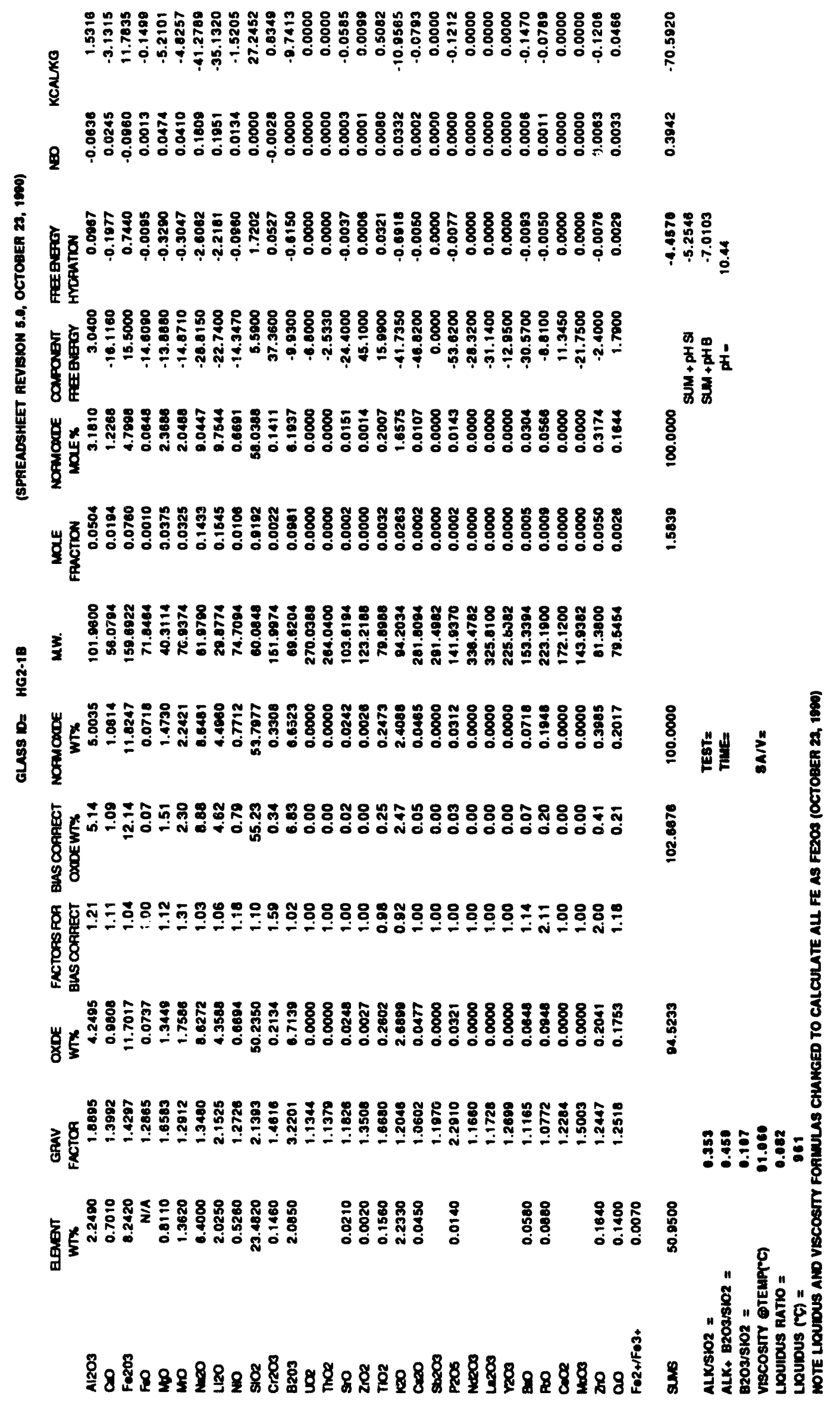




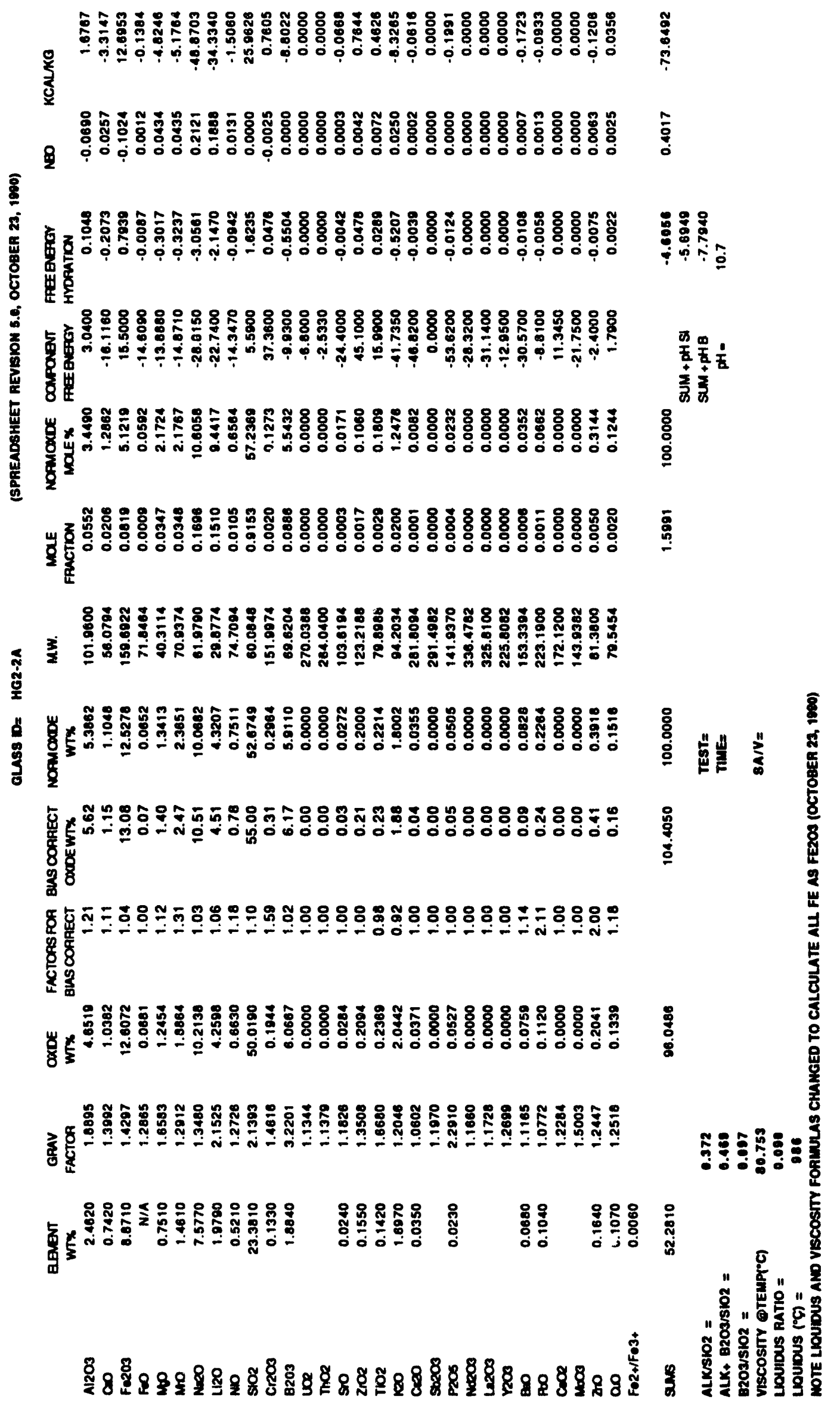




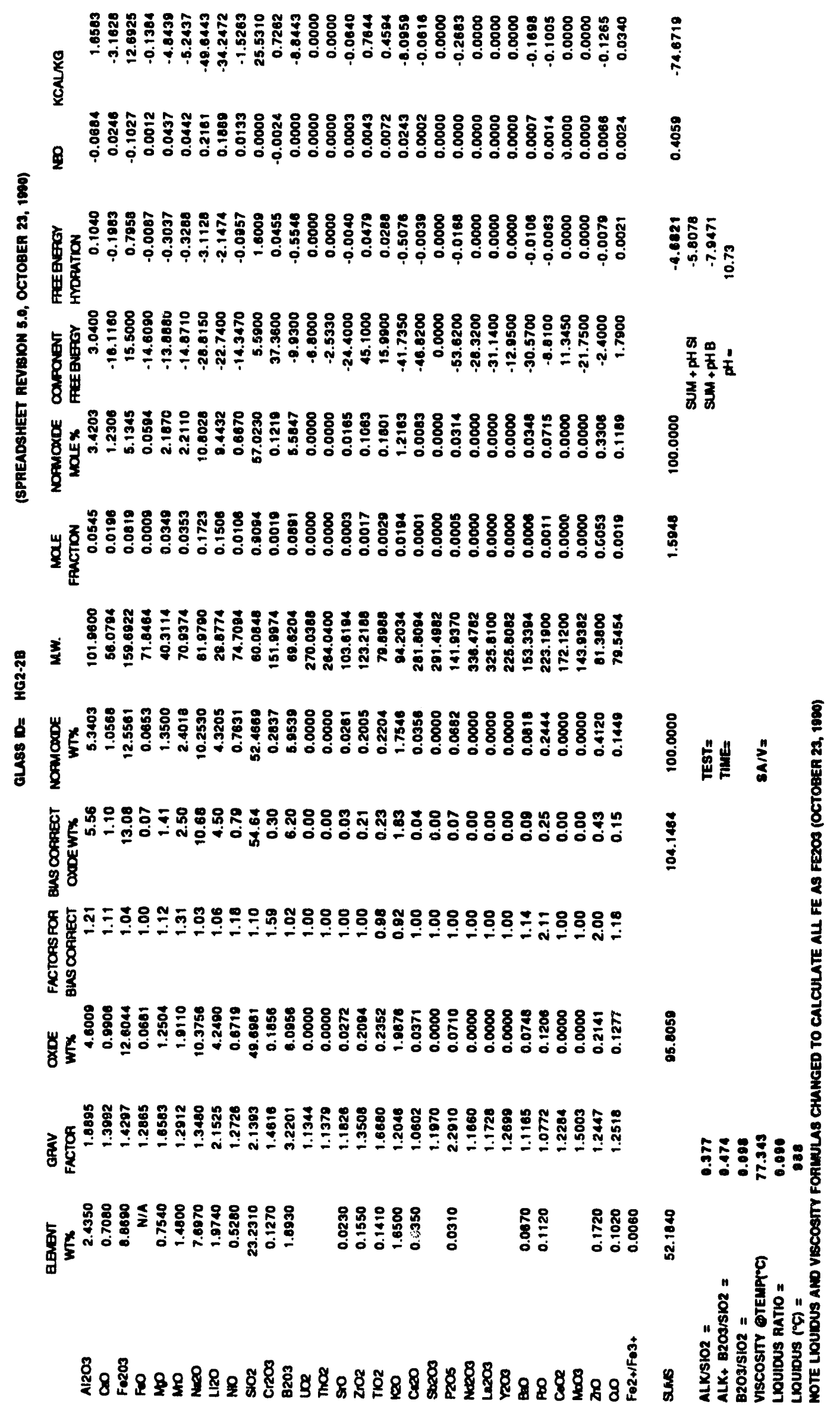




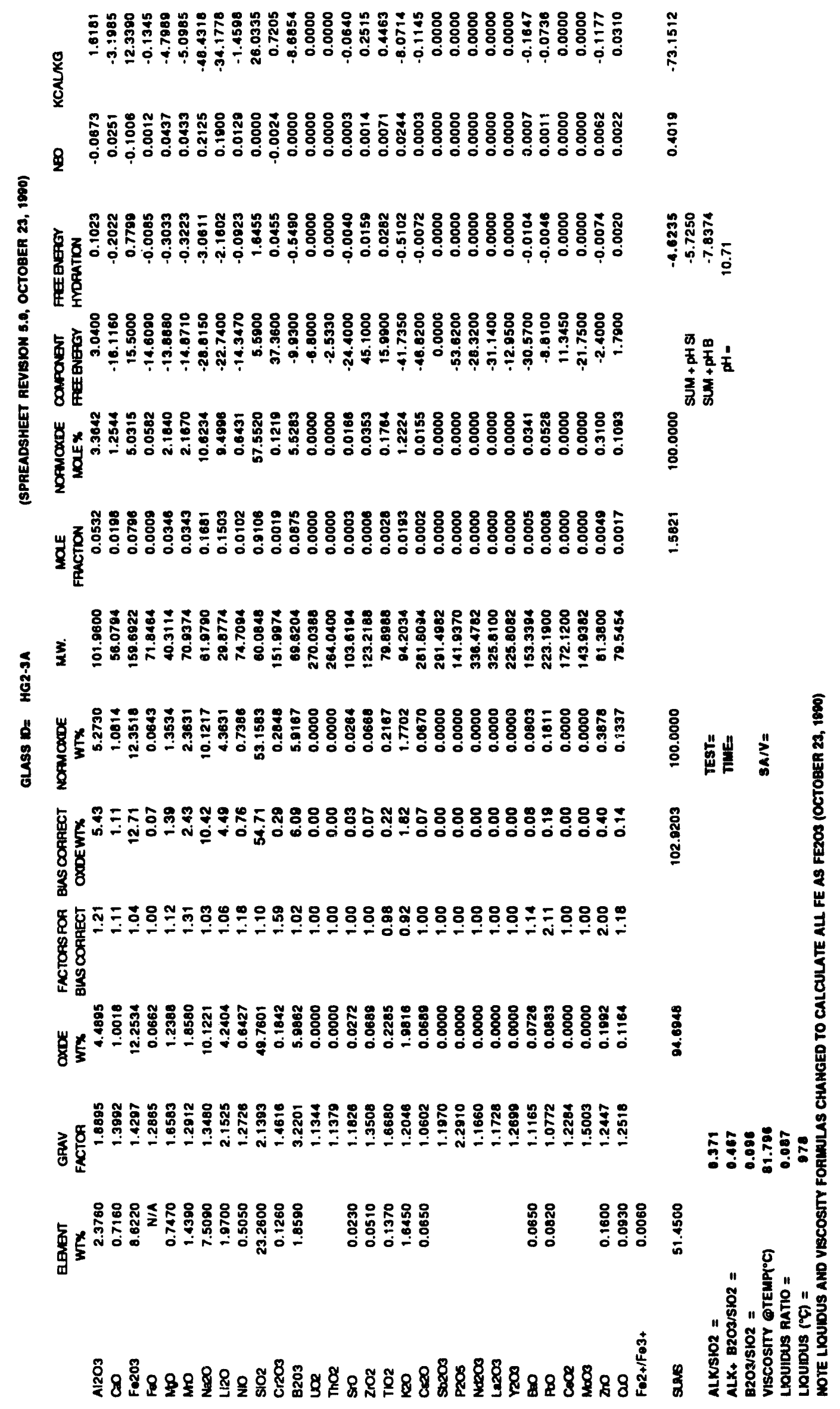




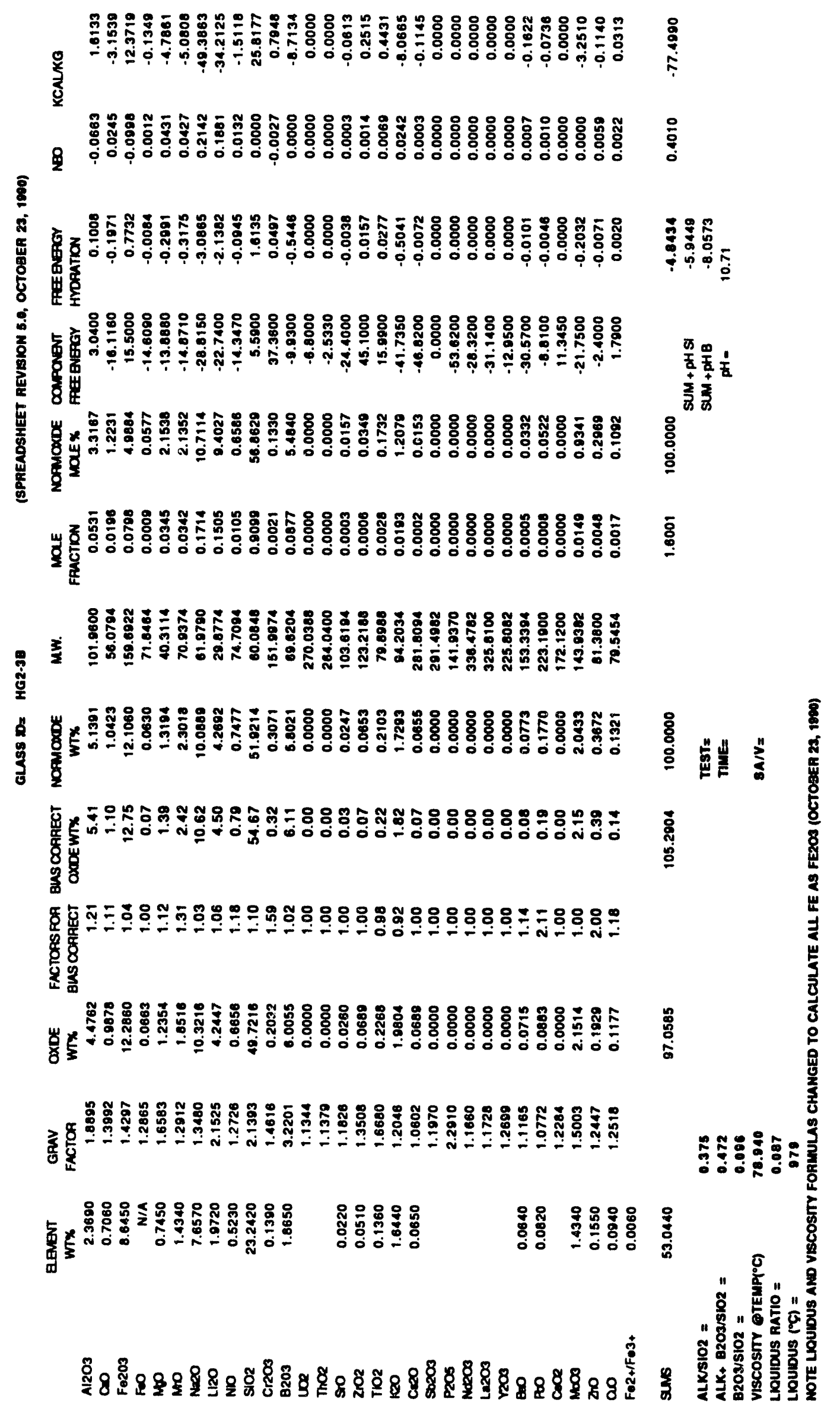




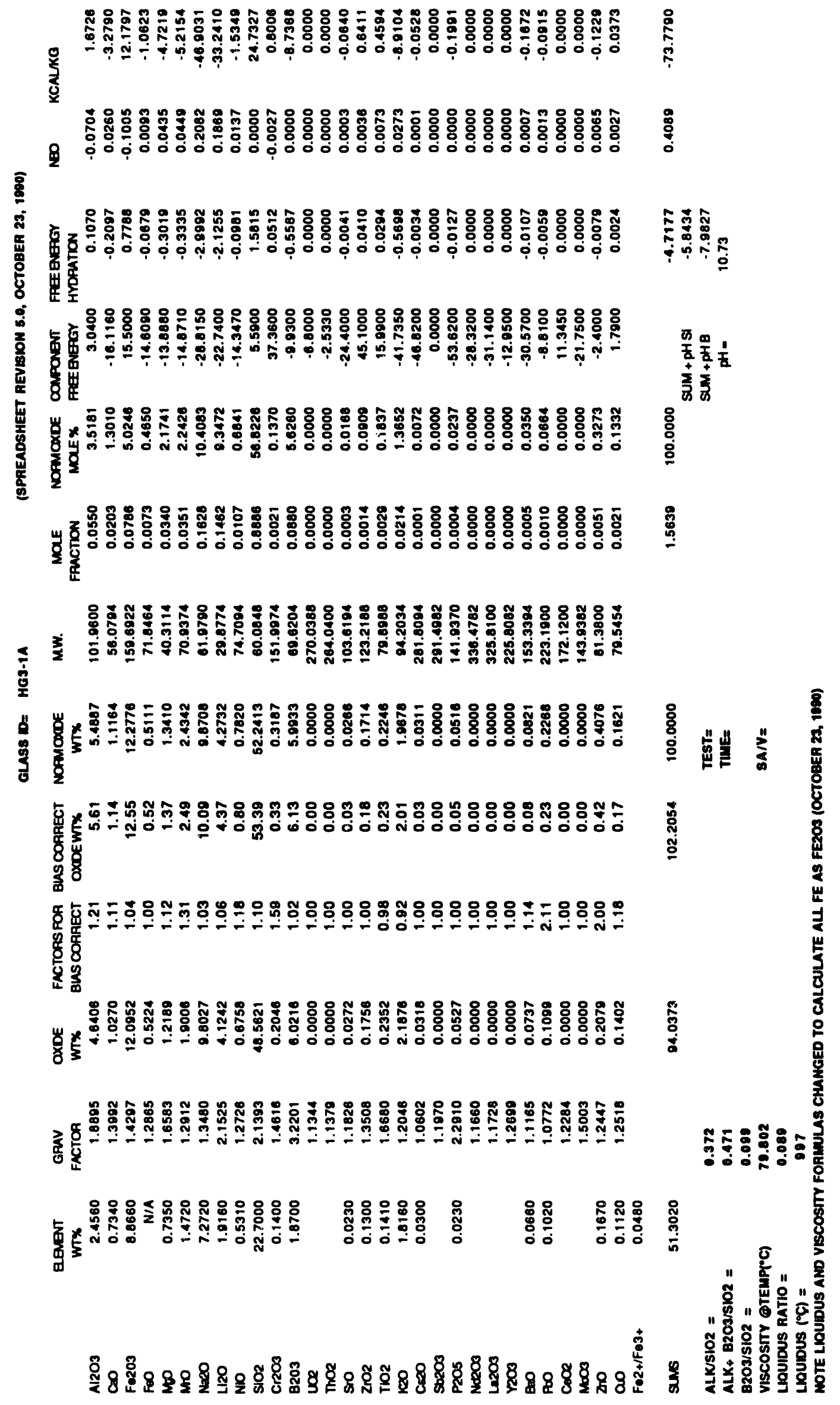




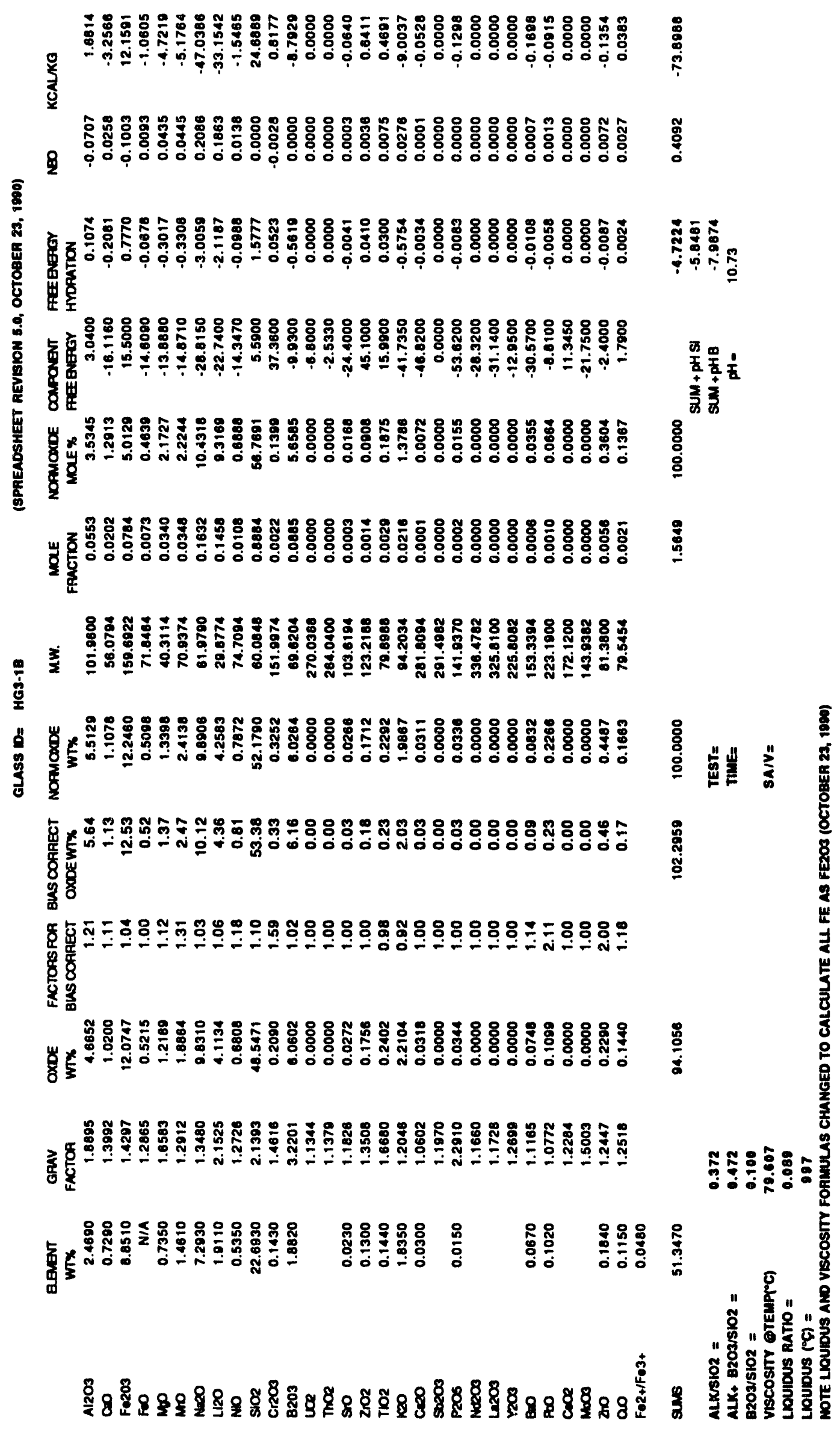




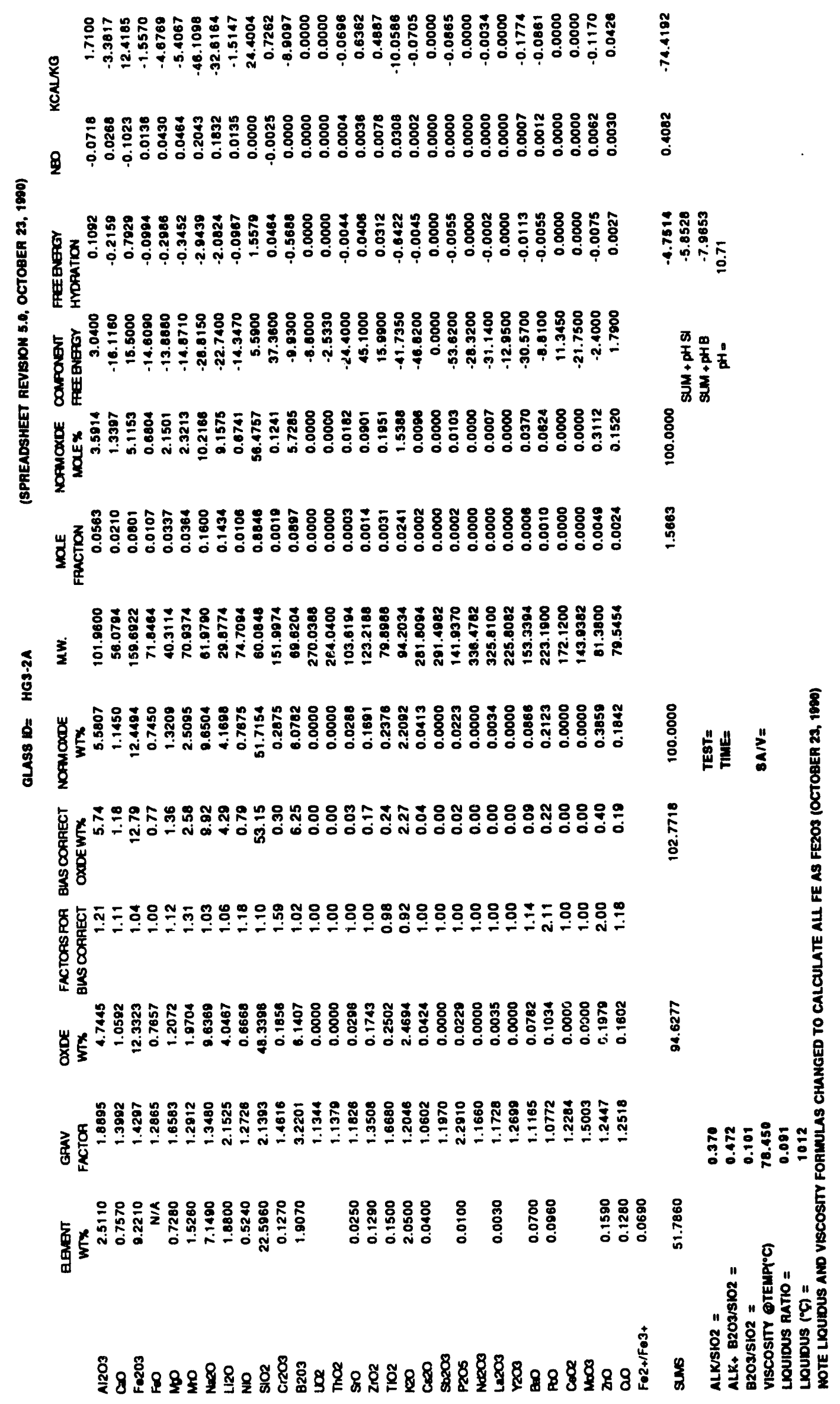




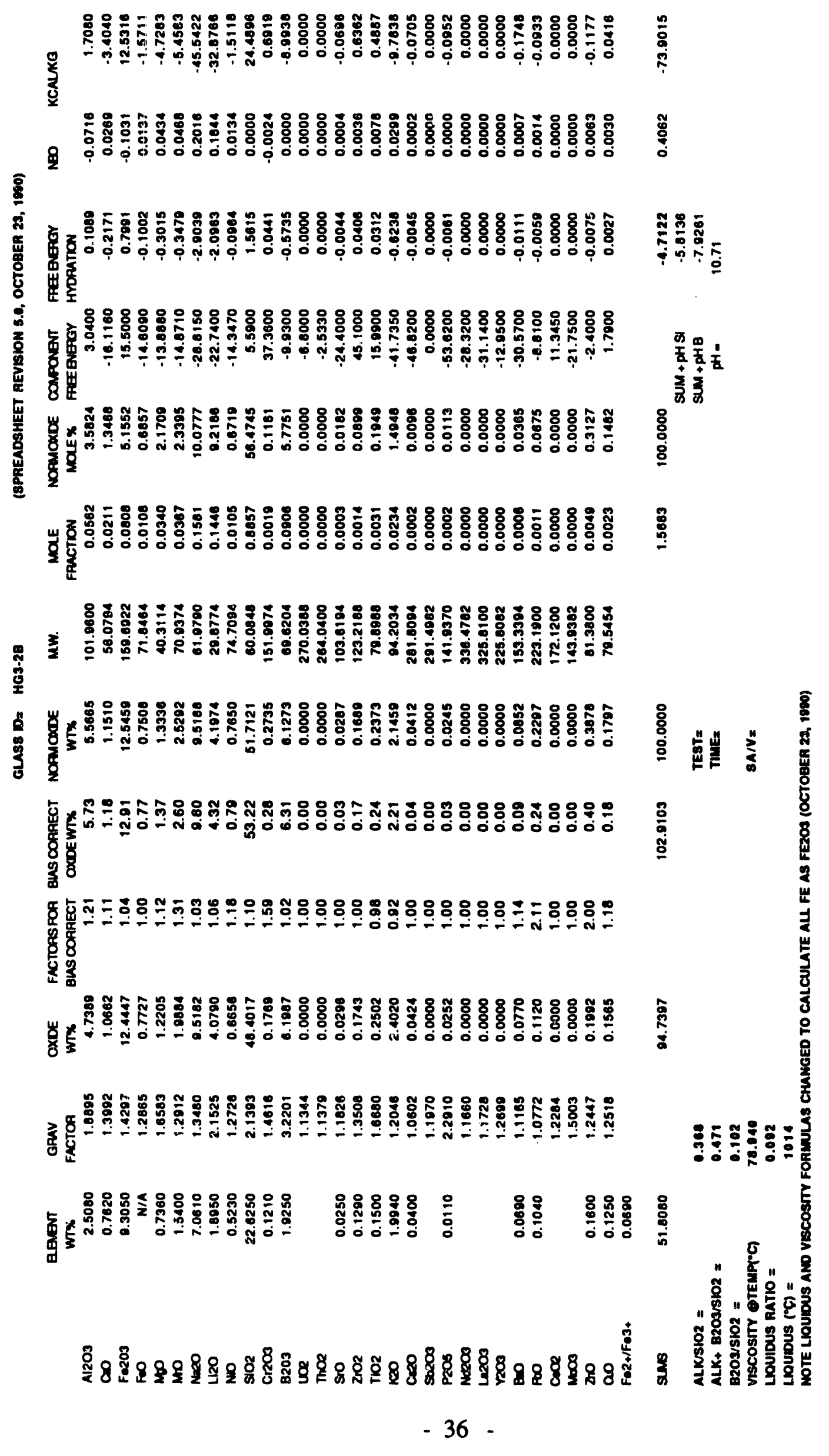




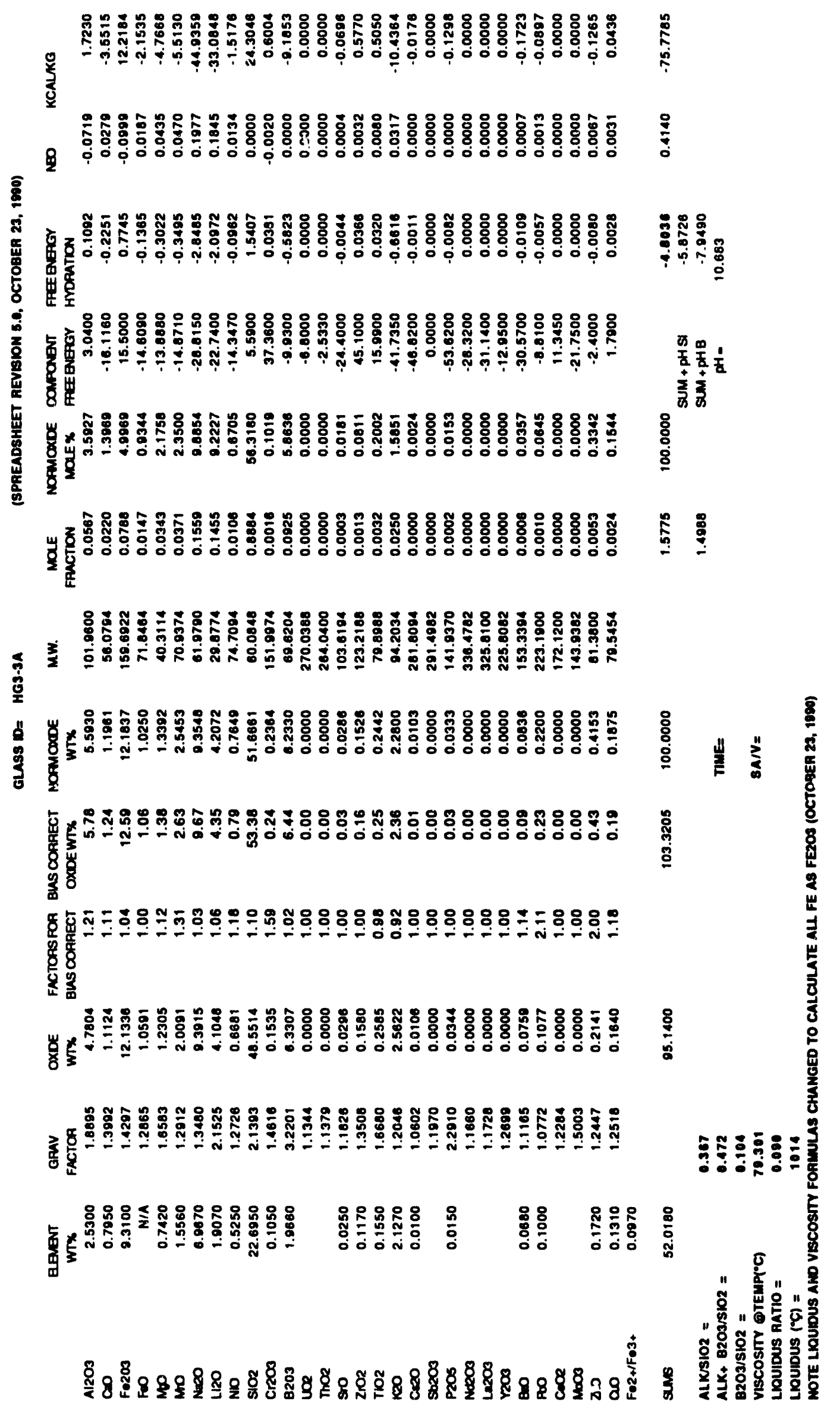




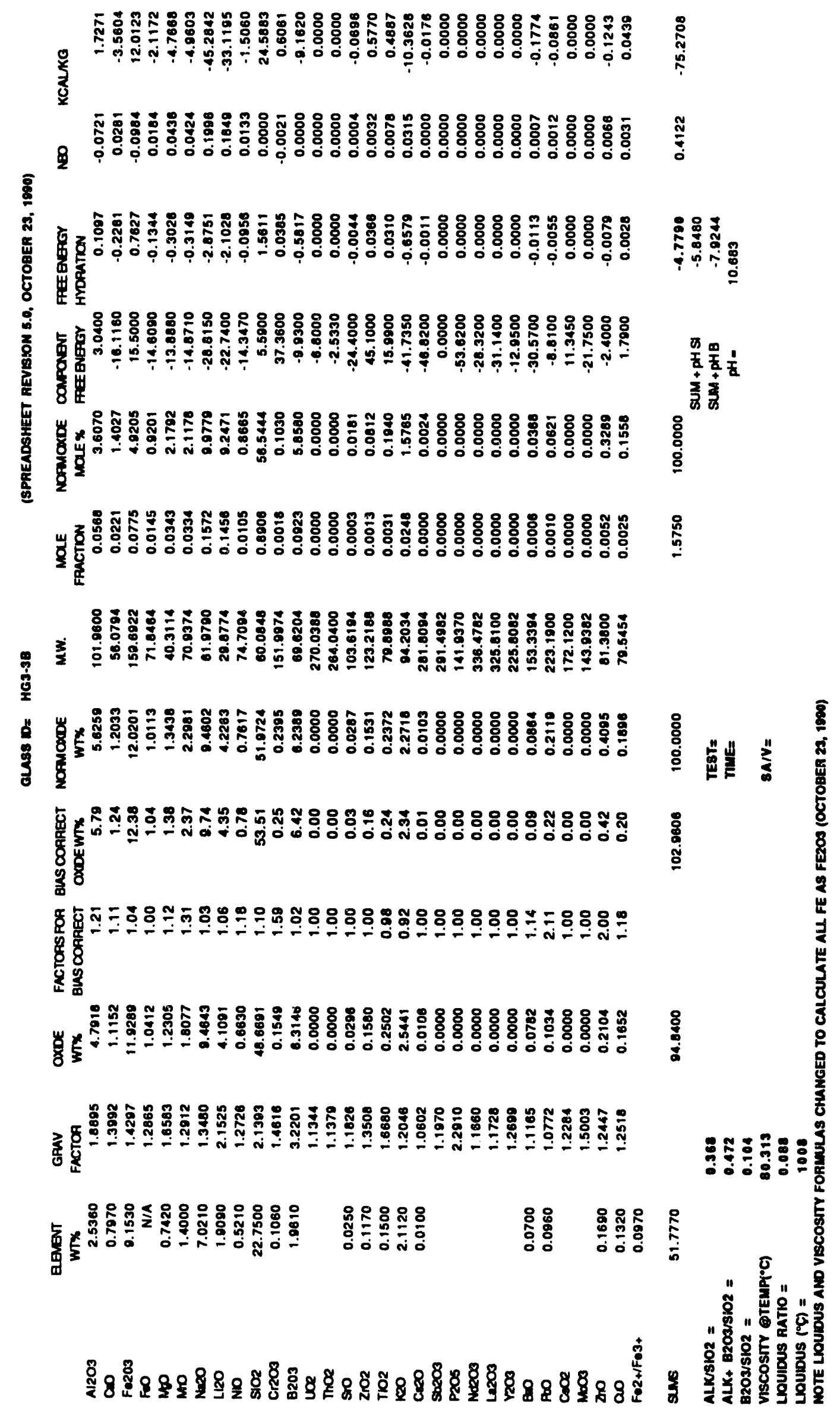




\section{APPENDIX II Leachate Multielement Standard Analyses}

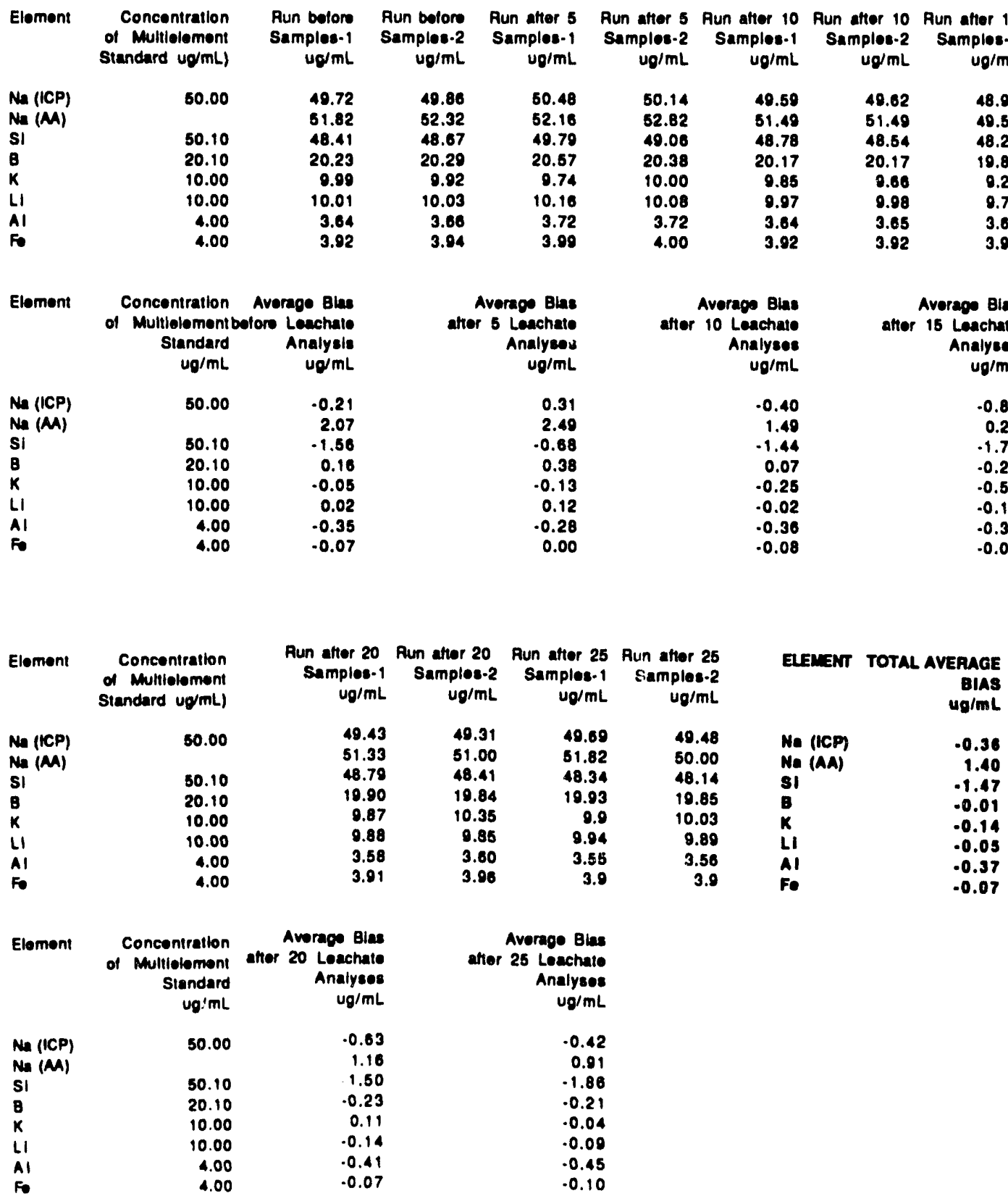


This page intentionally left blank.

-40 - 


\section{APPENDIX III Leachate Data for the IDMS Hg Campaigns 1, 2, 3}

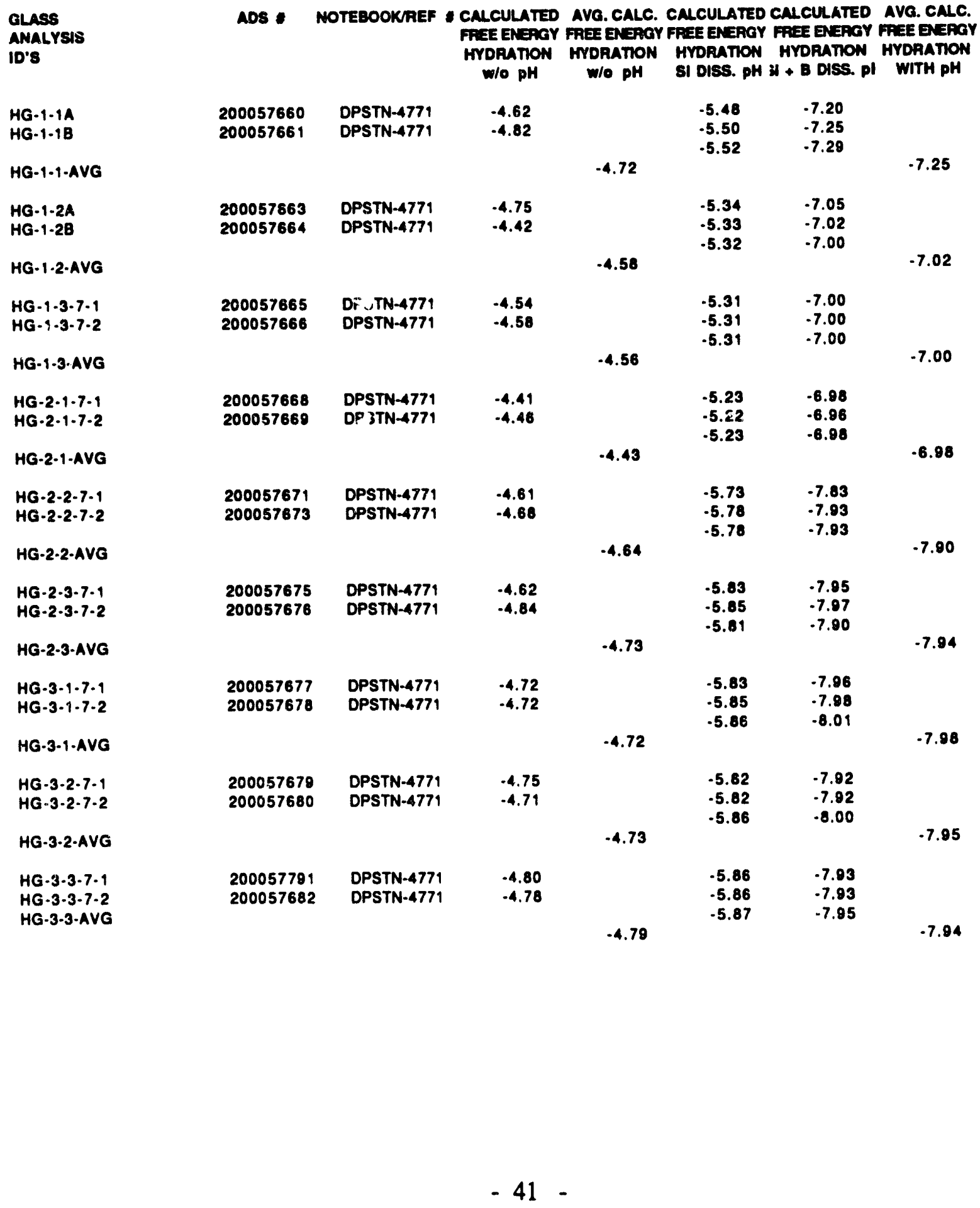




\begin{tabular}{|c|c|c|c|c|c|}
\hline $\begin{array}{l}\text { GLASS } \\
\text { ANALYSIS } \\
\text { ID'S }\end{array}$ & $\begin{array}{l}\text { WT. \% } \\
\text { W GLASS }\end{array}$ & $\begin{array}{l}\text { LI WT.\% } \\
\text { in GLASS }\end{array}$ & $\begin{array}{l}\text { Ma Wr. } \% \\
\text { W GLASS }\end{array}$ & $\begin{array}{l}\text { EI WT. } \% \\
\text { IN GLASS }\end{array}$ & $\begin{array}{l}\text { K WT.\% } \\
\text { IN CLASS }\end{array}$ \\
\hline $\begin{array}{l}\text { HG.1-1A } \\
\text { HG.1-1B }\end{array}$ & $\begin{array}{l}2.17 \\
2.21\end{array}$ & $\begin{array}{l}2.08 \\
2.03\end{array}$ & $\begin{array}{l}6.78 \\
6.85\end{array}$ & $\begin{array}{l}25.33 \\
23.53\end{array}$ & $\begin{array}{l}2.22 \\
2.22\end{array}$ \\
\hline HG.1-1.AVG & 2.10 & 2.05 & 6.82 & 24.43 & 2.22 \\
\hline $\begin{array}{l}\text { HG-1-2A } \\
\text { HG-1-2B }\end{array}$ & $\begin{array}{l}2.16 \\
2.17\end{array}$ & $\begin{array}{l}2.15 \\
2.15\end{array}$ & $\begin{array}{l}6.61 \\
6.43\end{array}$ & $\begin{array}{l}25.86 \\
25.89\end{array}$ & $\begin{array}{l}2.91 \\
2.18\end{array}$ \\
\hline HG-1.2-AVG & 2.17 & 2.15 & 6.52 & 25.87 & 2.55 \\
\hline $\begin{array}{l}\text { HG.1-3.7-1 } \\
\text { HG.1-3.7-2 }\end{array}$ & $\begin{array}{l}2.18 \\
2.16\end{array}$ & $\begin{array}{l}2.17 \\
2.34\end{array}$ & $\begin{array}{l}6.59 \\
6.56\end{array}$ & $\begin{array}{l}25.92 \\
25.71\end{array}$ & $\begin{array}{l}2.15 \\
2.17\end{array}$ \\
\hline HG.1-3.AVG & 2.17 & 2.26 & 6.57 & 25.81 & 2.16 \\
\hline $\begin{array}{l}\text { HG-2-1-7-1 } \\
\text { HG-2-1-7-2 }\end{array}$ & $\begin{array}{l}2.13 \\
2.13\end{array}$ & $\begin{array}{l}2.15 \\
2.15\end{array}$ & $\begin{array}{l}6.55 \\
6.59\end{array}$ & $\begin{array}{l}25.04 \\
25.83\end{array}$ & $\begin{array}{l}2.03 \\
2.05\end{array}$ \\
\hline HG-2-1-AVG & 2.13 & 2.15 & 6.57 & 25.80 & 2.04 \\
\hline $\begin{array}{l}\text { HG-2-2.7-1 } \\
\text { HG-2-2.7-2 }\end{array}$ & $\begin{array}{l}1.02 \\
1.83\end{array}$ & $\begin{array}{l}2.10 \\
2.09\end{array}$ & $\begin{array}{l}7.80 \\
7.93\end{array}$ & $\begin{array}{l}25.72 \\
25.55\end{array}$ & $\begin{array}{l}1.56 \\
1.52\end{array}$ \\
\hline HG-2-2-AVG & 1.03 & 2.10 & 7.87 & 25.63 & 1.54 \\
\hline 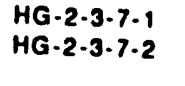 & $\begin{array}{l}1.90 \\
1.90\end{array}$ & $\begin{array}{l}2.09 \\
2.09\end{array}$ & $\begin{array}{l}7.73 \\
7.89\end{array}$ & $\begin{array}{l}25.59 \\
25.56\end{array}$ & $\begin{array}{l}1.51 \\
1.51\end{array}$ \\
\hline HG.2-3.AVG & 1.90 & 2.09 & 7.81 & 25.58 & 1.51 \\
\hline $\begin{array}{l}\text { HG.3-1.7-1 } \\
\text { HG.3-1.7-2 }\end{array}$ & $\begin{array}{l}1.91 \\
1.92\end{array}$ & $\begin{array}{l}2.03 \\
2.03\end{array}$ & $\begin{array}{l}7.49 \\
7.51\end{array}$ & $\begin{array}{l}24.97 \\
24.96\end{array}$ & $\begin{array}{l}1.67 \\
1.67\end{array}$ \\
\hline HG-3.1-AVG & 1.82 & 2.03 & 7.50 & 24.96 & 1.68 \\
\hline $\begin{array}{l}\text { HG.3.2.7-1 } \\
\text { HG.3.2.7.2 }\end{array}$ & $\begin{array}{l}1.95 \\
1.96\end{array}$ & $\begin{array}{l}1.99 \\
2.01\end{array}$ & $\begin{array}{l}7.36 \\
7.27\end{array}$ & $\begin{array}{l}24.86 \\
24.89\end{array}$ & $\begin{array}{l}1.89 \\
1.83\end{array}$ \\
\hline HG-3-2-AVG & 1.95 & 2.00 & 7.32 & 24.87 & 1.86 \\
\hline $\begin{array}{l}\text { HG-3.3.7-1 } \\
\text { HG-3.3.7-2 }\end{array}$ & $\begin{array}{l}2.01 \\
2.00\end{array}$ & $\begin{array}{l}2.02 \\
2.02\end{array}$ & $\begin{array}{l}7.18 \\
7.23\end{array}$ & $\begin{array}{l}24.06 \\
25.03\end{array}$ & $\begin{array}{l}1.96 \\
1.94\end{array}$ \\
\hline HG.3-3.AVG & 2.00 & 2.02 & 7.20 & 24.98 & 1.85 \\
\hline
\end{tabular}




\begin{tabular}{|c|c|c|c|c|c|c|c|c|}
\hline $\begin{array}{l}\text { PCT LEACHATE } \\
\text { IDS }\end{array}$ & ADS & RESEARCHER & NOTEBOOKAEF & $\begin{array}{l}\text { PCT } \\
\text { VERSHON }\end{array}$ & $\begin{array}{c}\text { MENSURE } \\
\text { pH }\end{array}$ & $\begin{array}{l}\text { MEASURED } \\
\text { B (ICP) } \\
\text { (pPm) }\end{array}$ & $\begin{array}{c}\text { MORMMLEED } \\
\text { Q (ICP) } \\
\text { (g/L) }\end{array}$ & $\begin{array}{c}\text { Loanopia } \\
\text { B (KP) } \\
\text { (g/L) }\end{array}$ \\
\hline $\begin{array}{l}\text { HG-1-1-7-1 } \\
\text { HG-1-1-7-2 } \\
\text { HG-1-1-7-3 } \\
\text { HG-1-1-AVG }\end{array}$ & $\begin{array}{l}200052676 \\
200052677 \\
200052678\end{array}$ & $\begin{array}{l}\text { B.J. Waters } \\
\text { B.J. Waters } \\
\text { B.J. Waters }\end{array}$ & $\begin{array}{l}\text { DPSTN-4789 } \\
\text { DPSTN-4789 } \\
\text { DPSTN-4789 }\end{array}$ & $\begin{array}{l}3.0 \\
3.0 \\
3.0\end{array}$ & $\begin{array}{l}10.41 \\
10.43 \\
10.45 \\
10.43\end{array}$ & $\begin{array}{l}14.37 \\
14.99 \\
15.32 \\
14.89\end{array}$ & $\begin{array}{l}0.66 \\
0.68 \\
0.70 \\
0.68\end{array}$ & $\begin{array}{l}-0.18 \\
-0.16 \\
-0.15 \\
-0.17\end{array}$ \\
\hline $\begin{array}{l}\text { HG-1 - } 2 \cdot 7-1 \\
\text { HG-1-2-7-2 } \\
\text { HG-1-2-7-3 } \\
\text { HG-1-2-AVG }\end{array}$ & $\begin{array}{l}200052670 \\
200052680 \\
200052681\end{array}$ & $\begin{array}{l}\text { B.J. Waters } \\
\text { B.J. Waters } \\
\text { BJ. Wators }\end{array}$ & $\begin{array}{l}\text { DPSTN-4789 } \\
\text { DPSTN-4789 } \\
\text { DPSTN-4789 }\end{array}$ & $\begin{array}{l}3.0 \\
3.0 \\
3.0\end{array}$ & $\begin{array}{l}10.40 \\
10.39 \\
10.38 \\
10.39\end{array}$ & $\begin{array}{l}15.65 \\
15.71 \\
15.91 \\
15.76\end{array}$ & $\begin{array}{l}0.72 \\
0.73 \\
0.73 \\
0.73\end{array}$ & $\begin{array}{l}-0.14 \\
-0.14 \\
-0.13 \\
-0.14\end{array}$ \\
\hline $\begin{array}{l}\text { HG-1-3-7-1 } \\
\text { HG-1-3-7-2 } \\
\text { HG-1-3-7-3 } \\
\text { HG-1-3-AVG }\end{array}$ & $\begin{array}{l}200052684 \\
200052685 \\
200052686\end{array}$ & $\begin{array}{l}\text { B.J. Waters } \\
\text { B.J. Waters } \\
\text { B.J. Waters }\end{array}$ & $\begin{array}{l}\text { DPSTN-4789 } \\
\text { DPSTN-4789 } \\
\text { DPSTN-4789 }\end{array}$ & $\begin{array}{l}3.0 \\
3.0 \\
3.0\end{array}$ & $\begin{array}{l}10.39 \\
10.39 \\
10.39 \\
10.39\end{array}$ & $\begin{array}{l}14.81 \\
14.74 \\
14.93 \\
14.83\end{array}$ & $\begin{array}{l}0.68 \\
0.68 \\
0.69 \\
0.68\end{array}$ & $\begin{array}{l}-0.17 \\
-0.17 \\
-0.16 \\
-0.17\end{array}$ \\
\hline $\begin{array}{l}\text { HG-2-1-7-1 } \\
\text { HG-2-1-7-2 } \\
\text { HG-2-1-7-3 } \\
\text { HG-2-1-AVG }\end{array}$ & $\begin{array}{l}200052687 \\
200052688 \\
200052689\end{array}$ & $\begin{array}{l}\text { B.J. Waters } \\
\text { B.J. Waters } \\
\text { B.J. Walers }\end{array}$ & $\begin{array}{l}\text { WSAC-NB-80-271 } \\
\text { WSRC-NB-90-271 } \\
\text { WSRC-NB-80-271 }\end{array}$ & $\begin{array}{l}3.0 \\
3.0 \\
3.0\end{array}$ & $\begin{array}{l}10.44 \\
10.43 \\
10.44 \\
10.44\end{array}$ & $\begin{array}{l}14.15 \\
14.75 \\
15.20 \\
14.70\end{array}$ & $\begin{array}{l}0.66 \\
0.69 \\
0.71 \\
0.69\end{array}$ & $\begin{array}{l}-0.18 \\
-0.16 \\
-0.15 \\
-0.16\end{array}$ \\
\hline $\begin{array}{l}\text { HG-2-2-7-1 } \\
\text { HG-2-2-7-2 } \\
\text { HG-2-2-7-3 } \\
\text { HG-2-2-AVG }\end{array}$ & $\begin{array}{l}200052692 \\
200052693 \\
200052694\end{array}$ & $\begin{array}{l}\text { B.J. Waters } \\
\text { B.J. Wature } \\
\text { B.J. Walors }\end{array}$ & $\begin{array}{l}\text { WSAC-NB-90-271 } \\
\text { WSAC-NB-90-271 } \\
\text { WSAC-NB-90-271 }\end{array}$ & $\begin{array}{l}\mathbf{3 . 0} \\
\mathbf{3 . 0} \\
\mathbf{3 . 0}\end{array}$ & $\begin{array}{l}10.70 \\
10.74 \\
10.74 \\
10.73\end{array}$ & $\begin{array}{l}14.85 \\
14.87 \\
14.86 \\
14.86\end{array}$ & $\begin{array}{l}0.77 \\
0.77 \\
0.77 \\
0.77\end{array}$ & $\begin{array}{l}-0.11 \\
-0.11 \\
-0.11 \\
-0.11\end{array}$ \\
\hline $\begin{array}{l}\text { HG-2-3-7-1 } \\
\text { HG-2-3-7-2 } \\
\text { HG-2-3-7-3 } \\
\text { HG-2-3-AVG }\end{array}$ & $\begin{array}{l}200052695 \\
200052696 \\
200052697\end{array}$ & $\begin{array}{l}\text { B.J. Waters } \\
\text { B.J. Waters } \\
\text { B.J. Waters }\end{array}$ & $\begin{array}{l}\text { WSRC-NB-90-271 } \\
\text { WSRC-NB-90-271 } \\
\text { WSRC-NB-90-271 }\end{array}$ & $\begin{array}{l}\mathbf{3 . 0} \\
\mathbf{3 . 0} \\
\mathbf{3 . 0}\end{array}$ & $\begin{array}{l}10.71 \\
10.72 \\
10.69 \\
10.71\end{array}$ & $\begin{array}{l}15.02 \\
14.04 \\
14.96 \\
14.87\end{array}$ & $\begin{array}{l}0.70 \\
0.79 \\
0.79 \\
0.79\end{array}$ & $\begin{array}{l}-0.10 \\
-0.10 \\
-0.10 \\
-0.10\end{array}$ \\
\hline $\begin{array}{l}\text { HG-3-1-7-1 } \\
\text { HG-3-1-7-2 } \\
\text { HG-3-1-7-3 } \\
\text { HG-3-1-AVG }\end{array}$ & $\begin{array}{l}200052700 \\
200052701 \\
200052702\end{array}$ & $\begin{array}{l}\text { B.d. Waters } \\
\text { B.J. Waters } \\
\text { B.J. Waters }\end{array}$ & $\begin{array}{l}\text { WSAC-NB-80-271 } \\
\text { WSRC-NB-90-271 } \\
\text { WSRC-NB-90-271 }\end{array}$ & $\begin{array}{l}3.0 \\
3.0 \\
3.0\end{array}$ & $\begin{array}{l}10.72 \\
10.73 \\
10.74 \\
10.73\end{array}$ & $\begin{array}{l}14.08 \\
14.36 \\
14.86 \\
14.43\end{array}$ & $\begin{array}{l}0.74 \\
0.75 \\
0.78 \\
0.75\end{array}$ & $\begin{array}{l}-0.13 \\
-0.13 \\
-0.11 \\
-0.12\end{array}$ \\
\hline $\begin{array}{l}\text { HG-3-2-7-1 } \\
\text { HG-3-2-7-2 } \\
\text { HG-3-2-7-3 } \\
\text { HG-3-2-AVG }\end{array}$ & $\begin{array}{l}200052703 \\
200052704 \\
200052705\end{array}$ & $\begin{array}{l}\text { B.J. Waters } \\
\text { B.J. Waters } \\
\text { B.J. Waters }\end{array}$ & $\begin{array}{l}\text { WSAC-NB-90-271 } \\
\text { WSRC-NB-90-271 } \\
\text { WSRC-NB-90-271 }\end{array}$ & $\begin{array}{l}3.0 \\
3.0 \\
3.0\end{array}$ & $\begin{array}{l}10.70 \\
10.70 \\
10.73 \\
10.71\end{array}$ & $\begin{array}{l}15.36 \\
15.04 \\
15.19 \\
15.20\end{array}$ & $\begin{array}{l}0.78 \\
0.77 \\
0.78 \\
0.78\end{array}$ & $\begin{array}{l}-0.10 \\
-0.11 \\
-0.11 \\
-0.11\end{array}$ \\
\hline $\begin{array}{l}\text { HG-3-3-7-1 } \\
\text { HG-3-3-7-2 } \\
\text { HG-3-3-7-3 } \\
\text { HG-3-3-AVG }\end{array}$ & $\begin{array}{l}200052709 \\
200052710 \\
200052712\end{array}$ & $\begin{array}{l}\text { B.J. Waters } \\
\text { B.J. Waters } \\
\text { B.J. Waters }\end{array}$ & $\begin{array}{l}\text { WSAC-NB-90-271 } \\
\text { WSAC-NB-90-271 } \\
\text { WSAC-NB-90-271 }\end{array}$ & $\begin{array}{l}3.0 \\
3.0 \\
3.0\end{array}$ & $\begin{array}{l}10.68 \\
10.68 \\
10.69 \\
10.68\end{array}$ & $\begin{array}{l}14.24 \\
14.60 \\
15.09 \\
14.64\end{array}$ & $\begin{array}{l}0.71 \\
0.73 \\
0.75 \\
0.73\end{array}$ & $\begin{array}{l}-0.15 \\
-0.14 \\
-0.12 \\
-0.14\end{array}$ \\
\hline
\end{tabular}




\begin{tabular}{|c|c|c|c|c|c|c|}
\hline $\begin{array}{l}\text { PCT LEACHATE } \\
\text { IDS }\end{array}$ & $\begin{array}{l}\text { EASUR: } \\
\text { LI (ICP) } \\
\text { (PPm) }\end{array}$ & $\begin{array}{c}\text { NORAMLLED } \\
\text { LI (ICP) } \\
\text { (g/L) }\end{array}$ & $\begin{array}{c}\text { Log NoFu } \\
\text { LI (KCP) } \\
\text { (g/L) }\end{array}$ & $\begin{array}{l}\text { MESUAED } \\
\text { K (AA) } \\
\text { (pPm) }\end{array}$ & $\begin{array}{c}\text { MORinMLESD } \\
K \text { (AA) } \\
\text { (o/L) }\end{array}$ & $\begin{array}{c}\text { LOG NOAM } \\
\text { K (AA) } \\
\left(O^{\prime} / \mathrm{L}\right)\end{array}$ \\
\hline $\begin{array}{l}\text { HG-1-1-7-1 } \\
\text { HG-1-1-7-2 } \\
\text { HG-1-1-7-3 } \\
\text { HG-1-1-AVG }\end{array}$ & $\begin{array}{l}13.14 \\
13.64 \\
13.89 \\
13.56\end{array}$ & $\begin{array}{l}0.64 \\
0.66 \\
0.68 \\
0.66\end{array}$ & $\begin{array}{l}-0.18 \\
-0.18 \\
-0.17 \\
-0.18\end{array}$ & $\begin{array}{l}8.80 \\
9.43 \\
9.65 \\
9.29\end{array}$ & $\begin{array}{l}0.40 \\
0.42 \\
0.43 \\
0.42\end{array}$ & $\begin{array}{l}-0.40 \\
-0.37 \\
-0.36 \\
-0.38\end{array}$ \\
\hline $\begin{array}{l}\text { HG-1-2-7-1 } \\
\text { HG-1-2-7-2 } \\
\text { HG-1-2.7-3 } \\
\text { HG-1-2-AVG }\end{array}$ & $\begin{array}{l}14.44 \\
14.46 \\
14.63 \\
14.51\end{array}$ & $\begin{array}{l}0.67 \\
0.67 \\
0.68 \\
0.67\end{array}$ & $\begin{array}{l}-0.17 \\
-0.17 \\
-0.17 \\
-0.17\end{array}$ & $\begin{array}{l}9.29 \\
0.25 \\
8.95 \\
9.16\end{array}$ & $\begin{array}{l}0.36 \\
0.36 \\
0.35 \\
0.36\end{array}$ & $\begin{array}{l}-0.44 \\
-0.44 \\
-0.45 \\
-0.44\end{array}$ \\
\hline $\begin{array}{l}\text { HG-1-3-7-1 } \\
\text { HG-1-3-7-2 } \\
\text { HG-1-3-7-3 } \\
\text { HG-1-3-AVG }\end{array}$ & $\begin{array}{l}14.00 \\
13.00 \\
14.07 \\
13.99\end{array}$ & $\begin{array}{l}0.62 \\
0.62 \\
0.62 \\
0.62\end{array}$ & $\begin{array}{l}-0.21 \\
-0.21 \\
-0.20 \\
-0.21\end{array}$ & $\begin{array}{l}8.94 \\
8.90 \\
8.95 \\
8.03\end{array}$ & $\begin{array}{l}0.41 \\
0.41 \\
0.41 \\
0.41\end{array}$ & $\begin{array}{l}-0.38 \\
-0.38 \\
-0.38 \\
-0.38\end{array}$ \\
\hline $\begin{array}{l}\text { HG-2-1-7-1 } \\
\text { HG-2-1-7.2 } \\
\text { HG-2-1-7-3 } \\
\text { HG-2-1-AVG }\end{array}$ & $\begin{array}{l}13.38 \\
13.88 \\
14.28 \\
13.85\end{array}$ & $\begin{array}{l}0.62 \\
0.65 \\
0.66 \\
0.64\end{array}$ & $\begin{array}{l}-0.21 \\
-0.19 \\
-0.18 \\
-0.18\end{array}$ & $\begin{array}{l}8.08 \\
8.30 \\
8.72 \\
8.37\end{array}$ & $\begin{array}{l}0.40 \\
0.41 \\
0.43 \\
0.41\end{array}$ & $\begin{array}{l}-0.40 \\
-0.38 \\
-0.37 \\
-0.39\end{array}$ \\
\hline 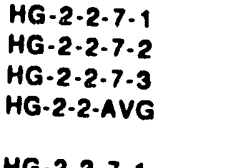 & $\begin{array}{l}15.20 \\
15.25 \\
15.21 \\
15.22\end{array}$ & $\begin{array}{l}0.73 \\
0.73 \\
0.73 \\
0.73\end{array}$ & $\begin{array}{l}-0.14 \\
-0.14 \\
-0.14 \\
-0.14\end{array}$ & $\begin{array}{l}7.03 \\
7.01 \\
6.00 \\
6.08\end{array}$ & $\begin{array}{l}0.46 \\
0.46 \\
0.45 \\
0.45\end{array}$ & $\begin{array}{l}-0.34 \\
-0.34 \\
-0.35 \\
-0.34\end{array}$ \\
\hline $\begin{array}{l}\text { HG-2-3-7.1 } \\
\text { HG-2-3-7.2 } \\
\text { HG-2-3-7-3 } \\
\text { HG-2-3-AVG }\end{array}$ & $\begin{array}{l}15.12 \\
14.92 \\
14.90 \\
14.98\end{array}$ & $\begin{array}{l}0.72 \\
0.71 \\
0.71 \\
0.72\end{array}$ & $\begin{array}{l}-0.14 \\
-0.15 \\
-0.15 \\
-0.14\end{array}$ & $\begin{array}{l}7.38 \\
6.41 \\
6.65 \\
6.81\end{array}$ & $\begin{array}{l}0.49 \\
0.42 \\
0.44 \\
0.45\end{array}$ & $\begin{array}{l}-0.31 \\
-0.37 \\
-0.36 \\
-0.35\end{array}$ \\
\hline $\begin{array}{l}\text { HG-3-1-7-1 } \\
\text { HG-3-1-7-2 } \\
\text { HG-3-1-7-3 } \\
\text { HG-3-1-AVG }\end{array}$ & $\begin{array}{l}14.22 \\
14.51 \\
14.90 \\
14.54\end{array}$ & $\begin{array}{l}0.70 \\
0.71 \\
0.73 \\
0.72\end{array}$ & $\begin{array}{l}-0.15 \\
-0.15 \\
-0.13 \\
-0.14\end{array}$ & $\begin{array}{l}7.38 \\
7.71 \\
8.16 \\
7.75\end{array}$ & $\begin{array}{l}0.44 \\
0.46 \\
0.49 \\
0.46\end{array}$ & $\begin{array}{l}-0.36 \\
-0.34 \\
-0.31 \\
-0.34\end{array}$ \\
\hline 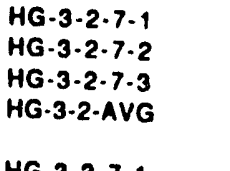 & $\begin{array}{l}14.57 \\
14.46 \\
14.63 \\
14.55\end{array}$ & $\begin{array}{l}0.73 \\
0.72 \\
0.73 \\
0.73\end{array}$ & $\begin{array}{l}-0.14 \\
-0.14 \\
-0.14 \\
-0.14\end{array}$ & $\begin{array}{l}10.16 \\
6.24 \\
8.28 \\
8.89\end{array}$ & $\begin{array}{l}0.55 \\
0.44 \\
0.45 \\
0.48\end{array}$ & $\begin{array}{l}-0.26 \\
-0.35 \\
-0.35 \\
-0.32\end{array}$ \\
\hline $\begin{array}{l}\text { HG.3-3-7.1 } \\
\text { HG.3-3.7-2 } \\
\text { HG-3-3-7.3 } \\
\text { HG.3-3.AVG }\end{array}$ & $\begin{array}{l}13.45 \\
13.78 \\
14.12 \\
13.78\end{array}$ & $\begin{array}{l}0.67 \\
0.68 \\
0.70 \\
0.68\end{array}$ & $\begin{array}{l}-0.18 \\
-0.17 \\
-0.16 \\
-0.17\end{array}$ & $\begin{array}{l}8.30 \\
8.79 \\
8.98 \\
8.69\end{array}$ & $\begin{array}{l}0.43 \\
0.45 \\
0.46 \\
0.45\end{array}$ & $\begin{array}{l}-0.37 \\
-0.35 \\
-0.34 \\
-0.35\end{array}$ \\
\hline
\end{tabular}




\begin{tabular}{|c|c|c|c|c|c|c|c|c|c|}
\hline $\begin{array}{l}\text { PCT LEACHATE } \\
\text { IDS }\end{array}$ & $\begin{array}{l}\text { MEASUPED } \\
\text { NA (ICP) } \\
\text { (ppm) }\end{array}$ & $\begin{array}{c}\text { MORWALEED } \\
\text { Ma (ICP) } \\
\text { (O/L) }\end{array}$ & $\begin{array}{l}\text { LOC Nopan. } \\
\text { (L) (ICP) } \\
\text { (O/L) }\end{array}$ & $\begin{array}{l}\text { MEASURED } \\
\text { Na (AA) } \\
\text { (PPM) }\end{array}$ & $\begin{array}{c}\text { MOAMALLEE } \\
\text { Na (AA) } \\
(g / L)\end{array}$ & $\begin{array}{c}\text { LOONOFaM } \\
\text { Na (AA) } \\
\text { (O/L) }\end{array}$ & $\begin{array}{l}\text { MEASUFED } \\
\text { SI (ICP) } \\
\text { (PPm) }\end{array}$ & $\begin{array}{l}\text { MOPMALLED } \\
\text { SI (ICP) } \\
\text { (g/L) }\end{array}$ & $\begin{array}{c}\text { LOG NOPAC } \\
\text { SI (ICP) } \\
\text { (O/L) }\end{array}$ \\
\hline $\begin{array}{l}\text { HG-1-1-7-1 } \\
\text { HG-1-1-7-2 } \\
\text { HG-1-1-7-3 } \\
\text { HG-1-1-AVG }\end{array}$ & $\begin{array}{l}43.81 \\
45.60 \\
46.76 \\
45.39\end{array}$ & $\begin{array}{l}0.64 \\
0.67 \\
0.69 \\
0.67\end{array}$ & $\begin{array}{l}-0.19 \\
-0.17 \\
-0.16 \\
-0.18\end{array}$ & $\begin{array}{l}45.70 \\
47.68 \\
49.18 \\
47.52\end{array}$ & $\begin{array}{l}0.67 \\
0.70 \\
0.72 \\
0.70\end{array}$ & $\begin{array}{l}-0.17 \\
-0.16 \\
-0.14 \\
-0.16\end{array}$ & $\begin{array}{l}91.22 \\
94.34 \\
95.70 \\
93.75\end{array}$ & $\begin{array}{l}0.37 \\
0.39 \\
0.39 \\
0.38\end{array}$ & $\begin{array}{l}-0.43 \\
-0.41 \\
-0.41 \\
-0.42\end{array}$ \\
\hline $\begin{array}{l}\text { HG-1-2-7-1 } \\
\text { HG-1-2-7-2 } \\
\text { HG-1-2-7-3 } \\
\text { HG-1-2-AVG }\end{array}$ & $\begin{array}{l}45.29 \\
45.11 \\
45.51 \\
45.30\end{array}$ & $\begin{array}{l}0.69 \\
0.69 \\
0.70 \\
0.69\end{array}$ & $\begin{array}{l}-0.16 \\
-0.16 \\
-0.16 \\
-0.16\end{array}$ & $\begin{array}{l}46.36 \\
47.85 \\
48.02 \\
47.41\end{array}$ & $\begin{array}{l}0.71 \\
0.73 \\
0.74 \\
0.73\end{array}$ & $\begin{array}{l}-0.15 \\
-0.13 \\
-0.13 \\
-0.14\end{array}$ & $\begin{array}{c}100.06 \\
99.67 \\
100.58 \\
100.10\end{array}$ & $\begin{array}{l}0.39 \\
0.39 \\
0.39 \\
0.39\end{array}$ & $\begin{array}{l}-0.41 \\
-0.41 \\
-0.41 \\
-0.41\end{array}$ \\
\hline $\begin{array}{l}\text { HG-1-3-7-1 } \\
\text { HG-1-3-7-2 } \\
\text { HG-1-3-7-3 } \\
\text { HG-1-3.AVG }\end{array}$ & $\begin{array}{l}42.09 \\
42.62 \\
43.17 \\
42.83\end{array}$ & $\begin{array}{l}0.65 \\
0.65 \\
0.66 \\
0.65\end{array}$ & $\begin{array}{l}-0.18 \\
-0.18 \\
-0.18 \\
-0.19\end{array}$ & $\begin{array}{l}44.04 \\
44.70 \\
44.54 \\
44.43\end{array}$ & $\begin{array}{l}0.67 \\
0.68 \\
0.68 \\
0.68\end{array}$ & $\begin{array}{l}-0.17 \\
-0.17 \\
-0.17 \\
-0.17\end{array}$ & $\begin{array}{l}96.23 \\
94.12 \\
95.19 \\
95.18\end{array}$ & $\begin{array}{l}0.37 \\
0.36 \\
0.37 \\
0.37\end{array}$ & $\begin{array}{l}-0.43 \\
-0.44 \\
-0.43 \\
-0.43\end{array}$ \\
\hline $\begin{array}{l}\text { HG-2-1-7-1 } \\
\text { HG-2-1-7-2 } \\
\text { HG-2-1.7-3 } \\
\text { HG-2-1-AVG }\end{array}$ & $\begin{array}{l}42.61 \\
44.45 \\
45.76 \\
44.27\end{array}$ & $\begin{array}{l}0.65 \\
0.68 \\
0.70 \\
0.67\end{array}$ & $\begin{array}{l}-0.19 \\
-0.17 \\
-0.16 \\
-0.17\end{array}$ & $\begin{array}{l}44.37 \\
46.53 \\
46.69 \\
45.86\end{array}$ & $\begin{array}{l}0.68 \\
0.71 \\
0.71 \\
0.70\end{array}$ & $\begin{array}{l}-0.17 \\
-0.15 \\
-0.15 \\
-0.16\end{array}$ & $\begin{array}{l}93.23 \\
96.86 \\
99.66 \\
96.65\end{array}$ & $\begin{array}{l}0.36 \\
0.37 \\
0.30 \\
0.37\end{array}$ & $\begin{array}{l}-0.44 \\
-0.43 \\
-0.41 \\
-0.43\end{array}$ \\
\hline $\begin{array}{l}\text { HG-2-2.7-1 } \\
\text { HG-2-2-7-2 } \\
\text { HG-2-2-7-3 } \\
\text { HG-2-2-AVG }\end{array}$ & $\begin{array}{l}62.82 \\
62.84 \\
62.57 \\
62.74\end{array}$ & $\begin{array}{l}0.80 \\
0.80 \\
0.80 \\
0.80\end{array}$ & $\begin{array}{l}-0.10 \\
-0.10 \\
-0.10 \\
-0.10\end{array}$ & $\begin{array}{l}64.90 \\
65.07 \\
63.41 \\
64.46\end{array}$ & $\begin{array}{l}0.83 \\
0.83 \\
0.81 \\
0.82\end{array}$ & $\begin{array}{l}-0.08 \\
-0.08 \\
-0.08 \\
-0.08\end{array}$ & $\begin{array}{l}105.23 \\
105.36 \\
104.75 \\
105.11\end{array}$ & $\begin{array}{l}0.41 \\
0.41 \\
0.41 \\
0.41\end{array}$ & $\begin{array}{l}-0.39 \\
-0.30 \\
-0.39 \\
-0.39\end{array}$ \\
\hline $\begin{array}{l}\text { HG-2-3-7-1 } \\
\text { HG-2-3-7-2 } \\
\text { HG-2-3-7-3 } \\
\text { HG-2-3-AVG }\end{array}$ & $\begin{array}{l}61.76 \\
61.31 \\
61.29 \\
61.45\end{array}$ & $\begin{array}{l}0.79 \\
0.79 \\
0.78 \\
0.79\end{array}$ & $\begin{array}{l}-0.10 \\
-0.11 \\
-0.11 \\
-0.10\end{array}$ & $\begin{array}{l}62.59 \\
62.09 \\
61.76 \\
62.15\end{array}$ & $\begin{array}{l}0.80 \\
0.80 \\
0.78 \\
0.80\end{array}$ & $\begin{array}{l}-0.10 \\
-0.10 \\
-0.10 \\
-0.10\end{array}$ & $\begin{array}{l}105.40 \\
106.75 \\
106.34 \\
106.16\end{array}$ & $\begin{array}{l}0.41 \\
0.42 \\
0.42 \\
0.42\end{array}$ & $\begin{array}{l}-0.38 \\
-0.38 \\
-0.38 \\
-0.38\end{array}$ \\
\hline $\begin{array}{l}\text { HG-3-1.7-1 } \\
\text { HG-3-1-7-2 } \\
\text { HG-3-1-7-3 } \\
\text { HG-3-1-AVG }\end{array}$ & $\begin{array}{l}56.49 \\
57.79 \\
59.48 \\
57.92\end{array}$ & $\begin{array}{l}0.75 \\
0.77 \\
0.79 \\
0.77\end{array}$ & $\begin{array}{l}-0.12 \\
-0.11 \\
-0.10 \\
-0.11\end{array}$ & $\begin{array}{l}57.05 \\
60.10 \\
60.76 \\
59.60\end{array}$ & $\begin{array}{l}0.77 \\
0.80 \\
0.81 \\
0.70\end{array}$ & $\begin{array}{l}-0.11 \\
-0.10 \\
-0.08 \\
-0.10\end{array}$ & $\begin{array}{c}98.54 \\
100.20 \\
102.09 \\
100.28\end{array}$ & $\begin{array}{l}0.39 \\
0.40 \\
0.41 \\
0.40\end{array}$ & $\begin{array}{l}-0.40 \\
-0.40 \\
-0.39 \\
-0.40\end{array}$ \\
\hline $\begin{array}{l}\text { HG-3-2-7-1 } \\
\text { HG-3-2-7-2 } \\
\text { HG-3-2-7-3 } \\
\text { HG-3-2-AVG }\end{array}$ & $\begin{array}{l}56.73 \\
56.18 \\
56.78 \\
56.56\end{array}$ & $\begin{array}{l}0.78 \\
0.77 \\
0.78 \\
0.77\end{array}$ & $\begin{array}{l}-0.11 \\
-0.11 \\
-0.11 \\
-0.11\end{array}$ & $\begin{array}{l}58.45 \\
56.79 \\
58.12 \\
57.79\end{array}$ & $\begin{array}{l}0.80 \\
0.78 \\
0.79 \\
0.79\end{array}$ & $\begin{array}{l}-0.10 \\
-0.11 \\
-0.10 \\
-0.10\end{array}$ & $\begin{array}{l}100.08 \\
99.61 \\
99.89 \\
99.86\end{array}$ & $\begin{array}{l}0.40 \\
0.40 \\
0.40 \\
0.40\end{array}$ & $\begin{array}{l}-0.40 \\
-0.40 \\
-0.40 \\
-0.40\end{array}$ \\
\hline $\begin{array}{l}\text { HG-3-3-7-1 } \\
\text { HG-3-3-7-2 } \\
\text { HG-3-3-7-3 } \\
\text { HG-3-3-AVG }\end{array}$ & $\begin{array}{l}51.57 \\
53.00 \\
54.66 \\
53.08\end{array}$ & $\begin{array}{l}0.72 \\
0.74 \\
0.76 \\
0.74\end{array}$ & $\begin{array}{l}-0.15 \\
-0.13 \\
-0.12 \\
-0.13\end{array}$ & $\begin{array}{l}53.31 \\
54.97 \\
54.14 \\
54.14\end{array}$ & $\begin{array}{l}0.74 \\
0.76 \\
0.75 \\
0.75\end{array}$ & $\begin{array}{l}-0.13 \\
-0.12 \\
-0.12 \\
-0.12\end{array}$ & $\begin{array}{l}92.48 \\
95.15 \\
07.49 \\
95.04\end{array}$ & $\begin{array}{l}0.37 \\
0.38 \\
0.39 \\
0.38\end{array}$ & $\begin{array}{l}-0.43 \\
-0.42 \\
-0.41 \\
-0.42\end{array}$ \\
\hline
\end{tabular}


This page intentionally left blank. 

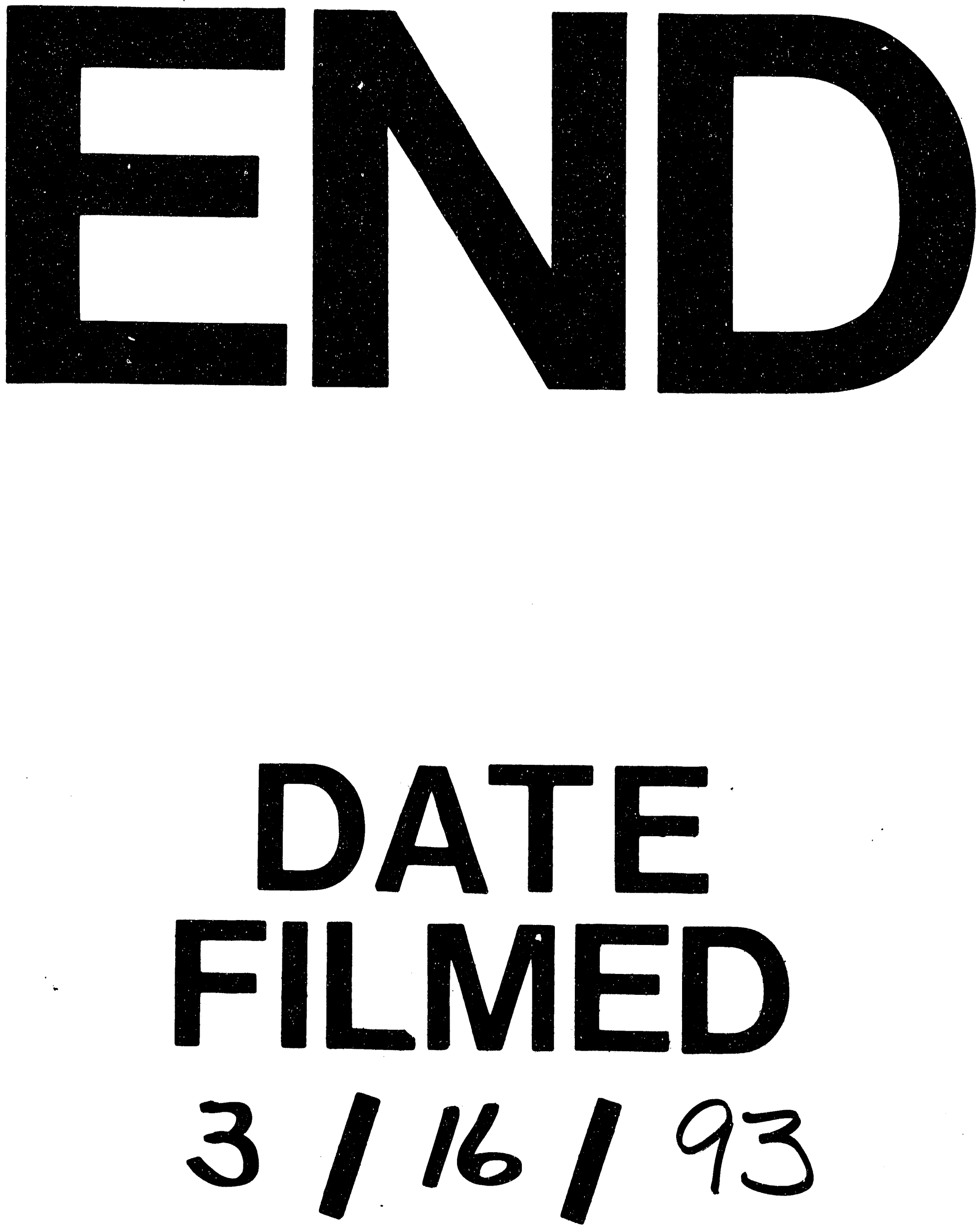
